\title{
Geray Hanedanının Osmanlı Devleti Topraklarında Kalan Maddi İzleri*
}

\author{
Hakan Kırımlı**
}

\begin{abstract}
$\ddot{O}_{z}$
Üç buçuk asır boyunca Kırım Hanlığı'na hükümdar veren Geray hanedanı mensupları XVI. yüzyıldan itibaren Osmanlı Devleti topraklarında yerleşmeye başlamışlardır. O kadar ki, XVIII. yüzyılda bu geniş hanedanın Osmanlı topraklarında yaşayan mensuplarının sayısı Kırım'da kalanların çok üzerine çıkmıştır. 1783'te Kırım Hanlı̆̆ı'nın Rusya tarafindan ortadan kaldırılmasını müteakip, Kuzey Kafkasya’ya yerleşenler dışında Geray hanedanı mensuplarının büyük çoğunluğu Osmanlı Rumelisi'nde toplanmıştır.

Osmanlı topraklarında yaşayan Geraylar burada geçirdikleri yüzyıllar içinde orada doğmuş, ölmüş ve sayısız mimarî eserler inşa ettirmişlerdir. Bu makalemiz bu coğrafyada Geraylardan kalabilen eserlerin bir dökümünü vermeyi amaçlamaktadır. Eski Osmanlı topraklarında Geraylardan geride kalan maddi izlerin büyük çoğunluğu mezar taşları olup, diğerleri iki türbe, bir köprü, bir çeşme, iki konak ile hamam, saray ve savunma kulesi kalıntılarından oluşmaktadır. Bunlar bugünkü Türkiye, Bulgaristan ve Yunanistan arazilerine dağılmış durumdadır. Muhakkak ki, günümüze ulaşabilen bu eserler bir zamanlar mevcut olanların çok küçük bir kısmından ibarettir. Söz konusu maddi izlerin tamamına yakını gayet harap ve restorasyona muhtaç durumdadır. Bununla birlikte, bu hanedan mensuplarının kendi vatanları olan Kırım'daki maddi izlerinin maruz bulunduğu muazzam tahribat göz önüne alındığında eski Osmanlı topraklarında kalabilen bu nispeten az sayıdaki izlerinin ve onların muhafazasının tarihî açıdan çok büyük önemi haiz olduğu ortaya çıkmaktadır.
\end{abstract}

Anahtar Kelimeler: Kırım, Kırım Hanlığı, Geraylar, Geray hanedanı, Rumeli, mezar taşları

* Bu araştırmamızın saha çalışmalarının bir kısmında destek aldığımız TÜBİTAK ve TİKA'ya müteșekkiriz.

** Doç. Dr., Bilkent Üniversitesi, Uluslararası İlişkiler Bölümü, Ankara/TÜRKIYY, hakankirimli@yahoo.com, ORCID: 0000-0003-2223-103X

DOI: 10.37879/belleten.2021.889

Makale Gönderim Tarihi: 22.05.2019 - Makale Kabul Tarihi: 16.11.2020

Belleten, Aralık 2021, Cilt: 85/Sayı: 304; 889-931 


\title{
Material Remains of the Geray Dynasty on the Territories of the Former Ottoman Empire
}

\begin{abstract}
Several members of the Geray dynasty, which reigned over the Crimean Khanate for more than three and a half centuries, began to settle on the territorries of the Ottoman Empire from the $16^{\text {th }}$ century on. So much so that as of the $18^{\text {th }}$ century, the number of the Gerays who settled in the Ottoman Empire outnumbered those who remained in their homeland, the Crimea. Following the destruction of the Crimean Khanate and the annexation of its territories by the Russian Empire in 1783, the remaining male members of the Geray dynasty in the Crimea also joined the others who had already been residing in Ottoman Rumelia, except for some who chose to settle in the North Caucasus.

During their centuries-long residence in the Ottoman Empire, members of the Geray dynasty built countless mansions, residences, fortifications, bridges, public baths, fountains, water mills, and other edifices. The present article attempts to bring about a general account of the existing material remains of the Geray dynasty on the territories of the former Ottoman Empire. These material remains basically consist of several sarcophagi and tombstones, two mausolea, a bridge, a fountain and the ruins of three mansions, a public bath and a defence tower. These surviving material remains are located in the territories of modern day Turkey, Bulgaria and Greece. Certainly, they constitute a very small portion of which had actually existed and almost all of them are in urgent need of care and repair.
\end{abstract}

Keywords: Crimea, Crimean Tatars, Geray, Geray dynasty, Rumelia, tombstones

\section{Giriş}

Kırım Hanlığg, 1475 tarihinden itibaren Osmanlı Devleti ile ittifak ve tabiyet ilişkisi içine girdi. Tam üç yüzyıl sürecek olan bu süreç içinde, hanlığın hükümdar hanedanı olan Geray sülalesi mensuplarından belirlenemeyecek kadar çok sayıda kimse, muhtelif sebeplerle Osmanlı topraklarına iskân edildi. O kadar ki, XVII. ve XVIII. yüzyıllarda Geray hanedanının Osmanlı Devleti’nde yaşayan mensuplarının sayısı Kırım’da kalanların çok üzerine çıkmış durumdaydı.

Geray hanedanı mensuplarının Osmanlı Devleti'nde uzun süreli olarak yerleşmeleri sürecinin Kırım hanzâdelerinin "rehin" olarak gönderilmesi olgusu ile başlamış olduğu yaygın bir görüştür. Evliya Çelebi, Kırım hanzâdelerinin Rumeli’ndeki "rehinliğgi”nin I. Meñli Geray Han döneminde (1475 yılında) Kırım Hanlı̆̆ı'nın 


\section{Maddi İzleri}

Osmanlı Devleti ile ittifak yahut tâbiyet ilişkisi içine girmesiyle ve onun bir şartı olarak ortaya çıktığını belirtmektedir¹. Ne var ki, "rehinlik" uygulamasının Kırım Hanlığı'nın Osmanlı himayesine girdiği 1475 yllından itibaren, hatta ondan sonraki en azından 30-35 yıl içinde başladığına dair herhangi bir delile sahip değiliz. Osmanlı tarihçisi Solakzâde Mehmed Hemdemî Çelebi rehinlik uygulamasının I. Meñli Geray Han'ın son yıllarında ve Sultan I. Selim (Yavuz) Osmanlı tahtında bulunduğu sırada başladığını ifade etmektedir. Solakzâde'ye göre, I. Meñli Geray Han'ın oğlu olup Sultan I. Selim (Yavuz) ile yakın ilişkide bulunan Saadet Geray Sultan (sonraki I. Saadet Geray Han) İstanbul'a "rehin" olarak gönderilmişti². Ancak, taht mücadelesi veren Şehzâde Selim'i (sonraki I. Sultan Selim'i) desteklemek maksadıyla Kırım'dan onunla beraber gelmiş olan Saadet Geray Sultan'ın Osmanlı Devleti'nde "rehin" sıfatıyla ikamet etmiş olması çok şüphelidir". Kırımlı tarihçi Abdullah Paşa zâde Rıdvan ise, I. Saadet Geray Han'ın saltanatında kardeşi Sahib Geray' "rehin" sıfatıyla ve "tahsil-i kemâl için" İstanbul'a gönderdiğini kaydetmektedir4. 1524'te Kazan tahtından feragatle ve zahiren hacca gitmek maksadıyla İstanbul'a geldiğini bildiğimiz ${ }^{5}$ Sahib Geray Han'ın da hanlık tahtında bulunmuş bir şahsiyet sıfatıyla "rehin" statüsünde olması eşyanın tabiatına uygun görünmemektedir. Bununla birlikte, muhtemelen XVI. asrın ilk yarısında bir şekilde "rehinlik" uygulamasının başladığı kanaatindeyiz. Söz konusu "rehin"lerin İstanbul'dan ziyade kendilerine çiftlikler tahsis edilen Rumeli'nde iskân edildikleri anlaşılmaktadır. Nitekim, 1570'de Rus Çarı IV. (Korkunç) İvan'ın elçisi olarak İstanbul'a gelen İvan P. Novosiltsev I. Devlet Geray Han'ın oğlunun (büyük ihtimalle Mehmed Geray Sultan'ın) Yanbolu'da ikamet etmekte olduğunu bildirmektedir ${ }^{6}$.

Böylece XVI. yüzylldan itibaren başlayan "rehinlik" uygulamasının XVIII. yüzyılın ikinci yarısına, yani Kırım Hanlığı'nın yıkılışına takaddüm eden 1768-1774

1 Evliya Çelebi, Evliyâ Çelebi Seyahatnâmesi, VII. Kitap, Hazırlayanlar: Seyit Ali Kahraman-Yücel Dağll-Robert Dankoff, İstanbul 2003, s. 180.

2 Solak-zâde Mehmed Hemdemî Çelebi, Solak-zâde Tarihi, G II, Hazırlayan: Vahid Çabuk, Ankara 1989, s. 106-107.

3 Yavuz Söylemez, "Kırım Hanlığı-Osmanlı Devleti Siyasi İlişkilerinde Rehin Usulü”, Türk Tarihi Arastirmalan Dergisi, G IV/S. 2 (Güz 2019), s. 100-102.

4 Abdullah ibn Rıdvan, Tevârîh-i Deşt-i Kipçak 'an Hitta-i Kirmm veya Tevârîh-i Tatar Hânân-ı Kadîm ve Ahvâl-i Deşt-i Kip̧̧ak, Hazırlayanlar: M. Akif Erdoğdu-Selçuk Uysal, İzmir 2012, s. 25-26.

5 Mihail Georgiyeviç Hudyakov, Oçerki po istorii Kazanskogo hanstva, Moskova 1991, s. 88-89; Serkan Acar, Kazan Hanlĭ̆g-Moskova Knezliği Siyasi İliskileri (1437-1552), Ankara 2013, s. 190-192.

6 Rus Elçi Raporlarnda Astrahan Seferi, Hazırlayan: İlyas Kamalov, Ankara 2011, s. 59. 
Osmanlı-Rus Savaşı'na kadar süregeldiği görülmektedir ${ }^{7}$. Kaide olarak İstanbul'da veya Rumeli'nde rehin olarak ikâmet ettirilen Geray sultanların tam olarak hangi vasıfları haiz oldukları açık değildir. Kırım Hanlığı’nın Osmanlı Devleti tâbiyetine girmesinden sonraki yaklaşık iki asırlık dönemde bu rehin (veya rehinler) tahttaki hanın hanzâdelerinden biriydi ${ }^{8}$. Genel olarak, XVII. yüzyll başlarına kadar rehinlerin veraset açısından birinci derecedeki hanzâdelerden olduğu ve bunların genellikle sonradan tahta çıktıkları görülmektedir ${ }^{9}$. Ancak, Kırım Hanlı̆̆ı’nın sonraki dönemlerinde bu özelliğin aranmadığı söylenebilir. Nitekim, XVII. yüzyıldan itibaren Geray hanedanına mensup olmak kaydıyla farklı kollardan kimselerin "rehin" olmalarıyla karşlaşılmaktadır. "Rehin" ibaresinin ilk akla gelebileceği şekilde küçültücü bir ima taşıdığını düşünmek doğru olmayacaktır. Nitekim, tarihçi Seyyid Mehmed Rıza rehinliği bir "mansıp" olarak zikretmektedir ${ }^{10}$.

Her ne kadar Gerayların Osmanlı topraklarında ikameti “rehin"lerle başlamış olsa da, sonraki dönemlerde Osmanlı Devleti’nde yaşayacak olan yüzlerce Geray hanedanı mensubunun "rehinlik"le hiçbir ilgisi yoktu. "Rehin" olanlar haricinde genel olarak Geray hanedanı mensuplarının kendi talepleriyle Rumeli'nde iskânı süreci XVI. yüzyılın ikinci yarısında ortaya çıkmış ve bilhassa XVII. yüzyılın ilk yarısından itibaren yoğunluk kazanmıştır. Bu durum XVI. yüzyılın ikinci ve XVII. yüzyılın ilk yarılarında Kırım'daki (Osmanlıların da doğrudan veya dolaylı olarak dahil olduğu) taht kavgalarında rakip Geray kolları arasında gayet kanlı hesaplaşmaların yaşanmış olmasıyla doğrudan ilişkilidir. Özellikle, II. Mehmed Geray Han, II. Gazi Geray Han, III. Mehmed Geray Han ve Canıbek Geray Han'ın saltanat dönemlerindeki olaylarda pek çok Geray sultan hayatını kaybettiğinden, diğerleri de can güvenliklerinden endişeye düşmüşlerdi. Bunlardan birçoğu bu firtınalı dönemlerde Osmanlı Devleti’nde ikameti daha güvenli bulmuşlardır.

7 Bu gibi Geraylar için XVIII. asırda dahi resmen "rehin" tabirinin kullanılması için, bk. T.C. Cumhurbaşkanlığı Devlet Arşivleri Başkanlığı Osmanlı Arşivi (İstanbul) (Bundan sonra BOA şeklinde gösterilecektir), Cevdet-Hariciye, Dosya no.: 77, Gömlek no.: 3849; İbnülemin-Hariciye, Dosya no.: 8, Gömlek no.: 722; Cevdet-Eyâlât-1 Mümtaze, Dosya no.: 10, Gömlek no.: 463; Cevdet-Hariciye, Dosya no.: 102, Gömlek no.: 5081.

8 İsmail Hakkı Uzunçarşıll, Osmanh Tarihi, G III/Kısım II, Ankara 1995, s. 33.

9 1608-1610 yıllarında tahtta bulunan I. Selâmet Geray Han'ın İstanbul'daki rehini, oğlu (ve halefi) Bahadır Geray Sultan (sonraki I. Bahadır Geray Han) idi. Seyyid Mehmed Rızâ, Es-Seb'uisSeyyâr fi Ahbâr-ı Mülukkit'-Tatar (İnceleme-Tenkitli Metin), Hazırlayan: Yavuz Söylemez, Ankara 2020 (Bundan sonra Es-Sebü's-Seyyâr olarak zikredilecektir), s. 190.

10 Es-Sebü's-Seyyâr, s. 136. 


\section{Maddi İzleri}

Tespitlerimize göre, ilk olarak II. (Semiz) Mehmed Geray Han dönemindeki (1577-1584) olaylarda hayatlarını tehlike altında gören ve Han'ın kardeşleri olan İslâm Geray Sultan (sonraki II. İslâm Geray Han), Sahib Geray Sultan ve Fetih Geray Sultan Osmanlı Devleti'nde ikamet etmek istemişlerdi. Osmanlı Devleti, onların Yanbolu'da ikametlerine izin verdi ${ }^{11}$. Özellikle 1620'lerde, III. Mehmed Geray Han'ın ve kardeşi Şahin Geray Sultan'ın baş aktör durumunda oldukları büyük çatışma ve kargaşalar sırasında pek çok hanzâde ve Geray sultan Kırım'ı terk ederek Rumeli'ne yerleşti. Bunlar arasında II. Gazi Geray Han'ın oğulları İnayet Geray Sultan (sonraki İnayet Geray Han), Pehlivan Hüsam Geray Sultan, Saadet Geray Sultan ve Ayvaz Geray Sultan, I. Selâmet Geray Han'ın oğulları Bahadır Geray Sultan (sonraki I. Bahadır Geray Han), Azamet Geray Sultan, Mübarek Geray Sultan, İslâm Geray Sultan (sonraki III. İslâm Geray Han) ve Safa Geray Sultan ile sâbık Kalgay Alp Geray Sultan'ın oğlu Meñli Geray Sultan da bulunmaktaydı ${ }^{12}$. Bu dönem, Geray sultanların Rumeli’nde yoğun ve kalıcı iskânının başlangıcıdır. Aynı şekilde, XVII. yüzyılın ikinci yarısında, özellikle IV. Mehmed Geray Han (1642-1644, 1654-1665) ve Âdil Geray Han (1665-1670) devirlerinde de uygulanan şiddet politikalarına bağlı olarak pek çok Geray sultan canlarını emniyette görmeyerek Kırım'ı terk etti. Bunlar Rumeli’ne ve Kuzey Kafkasya'ya yerleşti ${ }^{13}$. Bu şekilde, rakipleri yahut hasımları olan akrabalarının hükümdarlığı sırasında taht veya makamlarını kaybetmiş Geraylarla onların yakınları şahsî güvenlikleri kaygısıyla Osmanlı ülkesinde ikâmeti tercih etmişlerdir. İsmail Hakkı Uzunçarşılı'ya göre, Osmanlı Devleti de Gerayları Rumeli'nde ikamet ettirmek yoluyla onlar arasında kan dökülmesini önlemek maksadındaydı ${ }^{14}$.

Öte yandan, yeni tahta çıkan hanlar da seleflerinin yahut rakiplerinin kendilerine karşı potansiyel teşebbüslerinden endişeli oldukları için onların Kırım'dan uzakta bulunmalarını arzu etmekteydiler. Hatta, ileride görüleceği üzere, özellikle tehlikeli gördüklerinin bütünüyle Kırım gelişmelerinden kopuk olacakları Akdeniz adalarında ikametini istemekteydiler.

11 BOA, A.DVN.MHM.d., Defter no.: 46, s. 63, hüküm no.: 124; A.DVN.MHM.d., Defter no.: 46, s. 281, hüküm no.: 641; BOA, A.DVN.MHM.d., Defter no.: 48, s. 233, hüküm no.: 649; A.DVN. MHM.d., Defter no.: 48, s. 233, hüküm no.: 650.

12 Vasiliy Dmitriyeviç Smirnov, Krmskoe hanstvo pod verhovenstvom otomanskoy portı do naçala XVIII veka, Sankt Petersburg 1887, s. 498.

13 Es-Sebü's-Seyyâr, s. 237-240.

14 Uzunçarşılı, Osmanh Tarihi, C III/Kısım II, s. 40-41. 
Sınırları içinde çok sayıda Geray’ın ikâmet etmekte oluşu Osmanlı Devleti'ne önemli siyasi imkanlar sağlamaktaydı. Onlar vasıtasıyla Bahçesaray'daki Kırım Hanı'na daimî bir baskı yapılabileceği gibi, elinin altındaki Gerayların varlığı, mevcut hanın tahttan indirilmesi durumunda Osmanlı Devleti'ne Bahçesaray'a göndermek üzere geniş bir "Geray havuzu” temin ediyordu.

Gerayların bilhassa XVII.-XIX. yüzyıllar arasında Rumeli'nde yaşadıkları çiftliklerinin ve ikametgâhlarının bulunduğu yerleşim yerlerinin sayısının 200’ün çok üzerinde olduğu kanaatindeyiz ${ }^{15}$. Tespitlerimize göre bu çiftlik ve ikametgâhlar asıl olarak Edirne Vilâyeti dahilinde olup Silivri, Çatalca, Vize, Tekfurdağı, Burgaz (Lüleburgaz), Edirne, Aydos, Zağra-i Cedîd (Yeni Zağra), Zağra (Eski Zağra), Karinâbâd, Yanbolu, İslimye, Ahyolu Burgazı (Burgaz) ve Şumnu kazâlarında yoğunlaşmaktaydı. Görüldüğü üzere, bu kazaların hepsi (Şumnu Kazâsı dışında) bugünkü Bulgaristan ve Türkiye Trakyası arazisi üzerinde, Balkan Dağlarının güneyinden İstanbul önlerine kadar olan genel olarak düz ovalık bölge üzerinde yer almaktaydı. Gerayların Balkan Dağlarının kuzeyinde değil, güneyinde iskân edilmeleri bilinçli bir uygulamaydı. Bunun Osmanlı Devleti'nin politikası olduğu akla gelse de, aslında yerleşik bir âdet hâline gelen bu uygulama bizzat Kırım hanlarının taleplerinden kaynaklanmaktaydı. Kırım hanları Rumeli'ndeki Geray sultanların kendi izinleri olmaksızın Kırım Hanlığı arazisine gidip gelmelerini istemiyor, onların kendileri aleyhine birtakım hareketlere karışmalarından endişe ediyorlardı. Bu bakımdan, Geray sultanların hem izinsiz olarak hanlık topraklarına gidip gelmemeleri, hem de bu topraklara daha yakın olacakları Balkan Dağlarının kuzeyinde yerleşmemeleri hususunda Kırım hanlarının Osmanlı tarafindan ısrarlı taleplerde bulunduğu ve İstanbul'un da bu doğrultuda hareket ettiği görülmekte$\operatorname{dir}^{16}$. Bu bakımdan, Geray çiftlikleri Balkan Dağlarının güney tarafinda yoğun-

15 Arşiv ve saha çalışmalarımızda tespit edebildiğimiz Rumeli’ndeki (bugünkü Bulgaristan, Türkiye, Yunanistan ve Romanya topraklarındaki) bu gibi çiftlik ve ikamet yerlerinin sayısı 200 civarındadır. Ancak bu tür çiftliklerin pek çoğunun varlığından ancak ârızî bilgi ve belgelerle haberdar olunabildiğinden, bu sayının bundan çok daha yüksek olduğu görüşündeyiz.

16 Meselâ, 1756 baharında Kırım Hanı Halim Geray Han İstanbul'a yazarak Rumeli'ndeki Geray sultanların "bu husustaki kadim âdete riayetle" Balkan Dağlarının kuzeyinde ikamet etmelerinin ve Han’ın izni olmaksızın kendi tasarruflarıyla Kırım’a gidip gelmelerinin önlenmesini istemişti. Nitekim, Rumeli’nin Gerayların yaşadığı bölgelerinin kadılarına gönderilen bir fermanla Kırım Hanı'ndan izinsiz olarak Balkan Dağlarının kuzeyine geçmemeleri ve Kırım'a gidip gelmemeleri gereğinin Geray sultanlara "bir hoşca tenbih edilmesi" emredilmişti. BOA, A.DVN.MHM.d., Defter no.: 158, s. 58, hüküm no.: 159. Halim Geray Han'ın tahttan indirilmesine varan olaylara gerçekten de Rumeli’nden Kırım Hanlığı arazisine geçen -bilâhare tahta çıkacak olan başta Kırım Geray Sultan olmak üzere- Geray sultanların âmil olması dikkate şâyândır. 


\section{Maddi Izleri}

laşmıştı. Yine de, bu sıradağların kuzeyinde istinaî olarak Şumnu Kazası'ndaki birkaç çiftlik Gerayların tasarrufunda bulunmaktayd $1^{17}$.

Geray hanedanı mensupları Rumeli'ndeki bu çiftliklerinde sadece Kırım Hanlığı'nın mevcudiyeti süresince değil, hanlığın Rusya İmparatorluğu tarafindan ortadan kaldııldığı 1783 yılını takip eden bir asır boyunca, hatta birçok yerde ondan da sonrasında yaşamışlardır. Gerayların çiftliklerinin çoğu bugünkü Bulgaristan Devleti sınırları içinde kalan topraklarda yer almaktaydı. Bu toprakların bilfiil Osmanlı Devleti'nin hakimiyetinden çıktığı 1878 yılı sonrasında burada yaşayan Gerayların büyük çoğunluğu çiftliklerini terk etmek zorunda kalarak Osmanlıların elinde kalan bölgelere göç ettiler. Osmanlı Devleti’nin (ve bilâhare Türkiye Cumhuriyeti'nin) hakimiyetinden çımayan bugünkü Türkiye Trakyası'ndaki Geray sülalesi mensuplarının çoğu da gerek savaşlara ve yabancı işgallerine, gerekse sosyal, ekonomik ve şahsî sebeplere bağlı olarak XX. yüzyılın başları itibarıyla söz konusu bölgeden ayrılmış durumdaydı.

Geray hanedanı mensupları yüzyıllarca yaşadıkları Rumeli’ndeki yerleşim yerlerinde çok sayıda saray, konak, han, hamam, çeşme, köprü, türbe ve başka yapılar inşa ettirdiler. Ayrıca vefat ettiklerinde yine bu topraklara gömüldüklerinden, geride kendileri için yapılmış türbeler, lahitler ve mezar taşları bıraktılar. Bu gibi maddi kalıntılar esas olarak Rumeli arazisinde bulunmakla birlikte, hanedan mensuplarının geçici "sürgün" hayatı yaşadıkları Ege adalarında ve muhtelif sebeplerle sonradan yerleştikleri veya gömüldükleri İstanbul'da ve Anadolu'daki bazı yerlerde de görülmektedir. Ayrıca Geray hanedanı mensupları Rumeli'nde ve Rodos'ta vakıflar da kurmuşlardır.

Kırım topraklarında 1783 Rusya ilhakı ve özellikle de 1944 Büyük Sürgünü sonrasında hanlığa ve Geraylara ait eserlerin sistematik olarak ortadan kaldırıldığı bilinmektedir ${ }^{18}$. Şu cümleden olarak, Kırım'da Geray hanedanı mensuplarına ait günümüze ulaşabilen yegâne mezarlık, Bahçesaray'daki Han saray külliyesi içinde yer alan Han Camii'nin haziresinden geriye kalabilenlerden ibarettir ${ }^{19}$. Bu ba-

17 Bu istisnalar arasında en önemlisi Şumnu Kazâsı'na bağlı Vırbiçe (Vırbitsa) Çiftliği’ydi. Yine Şumnu-Osmanpazarı havalisinde bulunan ve Vırbiçe ile bağlantılı olan Çıtak, Eskiistanbulluk (Veliki Preslav), Kölemen ve Velibey çiftlikleri bu meyanda zikredilebilir.

18 Kırım'da Kırım Hanlığı devrinden kalabilen eserlerin tam bir dökümü için bk. Hakan KırımlNicole Kançal-Ferrari (Proje Yöneticileri), Hakan Kırıml-Nicole Ferrari-Kançal-Gökçe Günelİbraim Abdulla-Nariman Abdülvaap-Safiye Eminova-Gülşen Dişli (Yazarlar), Kirm'daki KirmTatar (Türk-İslâm) Mimarî Yadigârlar, (İkinci baskı), Ankara 2021.

19 Hansaray'daki Han Camii haziresindeki mevcut mezar taşlarının tam bir dökümü için bakınız, 
kımdan, günümüzde eski Osmanlı Devleti arazisinde Geray hanedanından kalan maddi izler çok büyük önem taşımaktadır. Bu maddi izler Türkiye, Bulgaristan ve Yunanistan devletlerinin toprakları üzerinde bulunmaktadır. Muhakkak ki, bu eski Osmanlı toprakları üzerindeki yapılar ve diğer maddi kalıntılar geçmişte mevcut olanların ancak küçük bir bölümüdür. Vandalizm, bakımsızlık, ilgisizlik ve başka sebepler dolayısıyla bu eserlerin çoğu ortadan kalkmıştır. Geriye kalabilenlerin en azından kayıt altına alınmaları onların korunabilmesi veya hiç değilse unutulmaması açısından çok önemlidir. Bu izlerin bazıları muhtelif araştırmalara ${ }^{20}$ konu olmuş, ancak bütün olarak ele alınmamıştır. Eski Osmanlı Devleti arazisi dahilinde Geraylara ait en fazla sayıda yapı ve maddi izler bugünkü Türkiye toprakları üzerinde kalabilmiştir. Bununla birlikte, (bir kısmı nispeten yakın geçmişte olmak üzere) ortadan kalkmış yahut kaldırılmış olanlar da önemli miktardadır.

Osmanlı devrinde Geray sülalesinin tasarrufunda veya mülkiyetinde olup, günümüzde Türkiye Trakyası'nda kalan 70 kadar çiftlik yahut köyü tespit ederek bunların istisnasız tamamında saha çalışması yapabildik. Bugünkü Bulgaristan sınırları dahilinde tespit edebildiğimiz ve çoğunda saha araştırması yapabildiğimiz Geraylara ait köy ve çiftlik sayısı ise 130 civarındadır. Gerek Türkiye'de, gerekse Bulgaristan'da arşiv ve kayıtlarda yer almayan, isim değişiklikleri dolayısıyla fark edilmeyen yahut bizim belirleyemediğimiz daha birçok çiftlik veya köy olduğundan şüphe etmiyoruz. Geray sülalesi mensuplarından kalan (Osmanlı devrine ait) tespit edebildiğimiz maddi kalıntıların bazılarının fotoğraflarını makalemizin sonunda takdim etmekteyiz. Araştırmamız kapsamına yalnızca Osmanlı dönemine ait yapı ve mezar taşları alınmış, Türkiye Cumhuriyeti döneminde yapılmış olanlar konumuzun dişında tutulmuştur.

\section{Bugünkü Türkiye Sınırları Dahilinde Kalan Maddi İzler}

Türkiye Trakyası’nda Geray hanedanı mensuplarının yaşamış oldukları çiftliklerde yaptırdıkları saray, konak, köprü, hamam, çeşme ve diğer yapılardan çok büyük kısmı günümüze gelememiştir. Türkiye'de Geraylardan kalan maddi kalıntıların en önemli bölümünü mezar taşları teşkil etmektedir. Tespit edebildiğimiz

Nicole Kançal-Ferrari, "Saray’a Bağlı Bir Cami ve Haziresi: Kırım Hanlığı’nın Payitahtı Bahçesaray'daki Hansaray'ı Haziresi”, Belleten, C LXVI/S. 246 (Ankara Ağustos 2002), s. 371 420.

20 Bu konuda en önemli çalışma, saha araştırmalarını birlikte yaptığımız Nicole Kançal-Ferrari'ye ait yayımlanmamış bir yüksek lisans tezidir: "Kırım Hanlarının İmar Faaliyeti ve Mezar Taşları", İstanbul Üniversitesi, İstanbul 1997. 


\section{Maddi İzleri}

kadarılya toplam sayısı 50 'yi geçen ${ }^{21}$ bu mezar taşlarının XVII. asrın sonlarına ait olan biri dışında tamamı XVIII. ve XIX. yüzyıllara aittir. Özellikle sâbık hanların, kalgayların, nureddinlerin, hanzâdelerin ve onların hanım ve kızlarının mezar taşlarının genellikle gayet kaliteli mermerden yapılması ve birçok hâlde yine mermerden gösterişli lahitler üzerine dikilmeleri karakteristiktir. Bu genel özellikler, Geray hanedânı mensuplarının kabirlerini sıradan insanlarınkinden ayırt edebilmeyi kolaylaştırmaktadır. Bununla birlikte, Geraylara ait olup da çok daha mütevazı birçok mezar taşları bulunduğunu da kaydetmek gerekir²2.

Tespit edebildiğimiz kadarıyla, Geraylara ait Türkiye'deki mezar taşları İstanbul, Saray, Subaşı, Hayrabolu, Çatalca, Kırklareli, Vize, Pınarhisar, Çorlu, Pınarbaşı/Paşaköy, Evrensekiz, Edirköy, Ulubat ve Çeşme gibi yerleşim yerlerindeki bazı cami hazirelerinde ve müzelerde bulunmaktadır. Bunlardan başka, Tekirdağ’ın Saray İlçesi’nin Karapürçek Köyü’nde III. Selim Geray Han Köprüsü, İstanbul'un Çatalca İlçesi'ne bağı Subaşı Kasabası'nda Selim Geray Sultan (sonraki II. Selim Geray Han) Çeşmesi, yine aynı yerde Geraylara ait bir hamamın kalıntısı ve bazı diğer yapı izleri bugün de mevcuttur. Sözünü ettiğimiz bu şehir ve kasabalarda dahi günümüze gelebilenler bir zamanlar mevcut olanların yalnızca küçük kısmı olup, diğerleri zaman içinde yok edilmiştir. Bu büyük tarih tahribatının sebepleri arasında cahillik, ilgisizlik, bakımsızlık, tabiatın tesirleri ve hırsızlık başta yer almaktadır.

\section{İstanbul}

Kaide olarak Tanzimat dönemine kadar Gerayların (normal şartlarda) İstanbul'da daimî ikametine izin verilmemekteydi. Yine de, aralarında sabık hanların da bulunduğu birçok Geray hanedanı mensubu istisnai olarak muhtelif zaman aralıklarında Osmanlı payitahtında yaşamış, burada ölmüş veya bir şekilde buraya gömülmüştür. Bunlardan Eyüp Sultan Türbesi haziresine defnedildiğini bildiğimiz I. Saadet Geray Han ${ }^{23}$ ile Beşiktaş’taki Yahya Efendi Tekkesi haziresine

21 Geraylara ait olduğunu kesin olarak tespit edebildiğimiz mezar taşlarının yanı sıra, kırık ve ait olduğu kişinin kimliği belli olmayan pek çok başka mezar taşları ile de karşılaştık. Bunlardan en azından bir kısmının Geray sülalesine ait olması kuvvetle muhtemeldir. Bu bakımdan, Türkiye'de Geraylara ait (XX. yüzyıl öncesine ait) mevcut mezar taşlarının sayısını 60-70 arası olarak da ifade edebiliriz.

22 Meselâ, II. Fetih Geray Han’ın Tekirdağ’a bağlı Saray ilçe merkezindeki Ayas Paşa Camii haziresinde bulunan baştaşı, onun bir han olduğu düşünüldüğünde ve benzerleriyle kıyaslandığında şaşılacak kadar mütevazıdır.

23 Es-Sebü's-Seyyâr, s. 119. 
defnedilen İnayet Geray Han'ın ${ }^{24}$ mezarları günümüze ulaşamamıştır. Bu iki han dışında belirlenemeyecek sayıda Geray hanedanı mensubunun İstanbul mezarlıklarında gömülü olduğuna hiç şüphe yoksa da, birkaçı dışında bunların mezarları kaybolmuş yahut tarafimızdan tespit edilememiştir. İstanbul mezarlıklarında tespit edebildiğimiz Geray hanedanı mensuplarına ait kabirler şunlardır:

Eyüp Mihrişah Valide Sultan Külliyesi-Sıbyan Mektebi haziresinde:

Gazi Geray Sultan (II. Devlet Geray Han’ın oğlu, ölümü: Hicrî 1147 [Milâdî 1734-1735) [Hazire no.: 1052]

Zeyneb Kadın (II. Kaplan Geray Han zâde Selim Geray Sultan'ın bikeçi [cariyesi], ölümü: Hicrî 15 Ramazan 1256 [Milâdî 10 Kasım 1840] (Hazire no.: 1003]

Fatma Sultan (II. Kaplan Geray Han zâde Selim Geray Sultan’ın kizı, ölümü: Hicrî 1289 [Milâdî 1872-1873]) [Hazire no.: 1004] ${ }^{25}$

Topkapı Maltepe Mezarlı̆ğ'nda:

Saadet Geray Paşa (Salih Geray Sultan’nn oğlu, ölümü: Hicrî 22 Rebîyülâhir 1300 [Milâdî: 2 Mart 1883])

Üsküdar'daki Alaca Minare (Şeyh Sadık Efendi) Tekkesi haziresinde:

Ayşe Hanım (Kuban Hanı Şahbaz Geray Han’ın kızı, ölümü: Hicrî Rebîyülâhir 1206 [Milâdî Ağustos 1801])

Kılıç Ali Paşa Camii haziresinde:

Hanife Haniye Hanım (Mehmed Geray Sultan zâde Sultan Saadet [Sagat]

Geray'ın kızı, ölümü: Hicrî 17 Safer 1316 [Milâdî 7 Temmuz 1898]).

İnayet Geray Han'ın mezar taşının en azından 1806 tarihine kadar mevcut olduğu Es-Sebü’sSeyyâr'a yazılan bir derkenardan anlaşılmaktadır. Es-Sebü's-Seyyâr, s. 186.

25 Bu baştaşının kitabesinde, "Kırım hanlarından Selim Geray kerîmesi Fatma Sultan" ibaresi yazılıdır. Ancak, Kırım tahtına çıkmış son Selim Geray olan III. Selim Geray Han 73 yaşındayken 1786'da vefat ettiğinden, onun kendisinden 86 sonra vefat edecek bir kızı olması hiç muhtemel gözükmemektedir. Esasen, bu gibi kayıtlarda Geray sultanların (konunun ayrıntısına vâkıf olmayan hanedan dışından kişilerce) han olarak zikredilmeleriyle sıkça karşılaşmaktayız. Bu bakımdan, baştaşında adı geçenlerin Çatalca'nın Subaşı Köyü'nde yaşamış ve gayet nüfuzlu şahsiyetler olarak tanınan II. Kaplan Geray Han zâde Selim Geray Sultan ile kızı Fatma Sultan Hanî olduğu bizce şüphesizdir. Nitekim, Osmanlı belgelerinde (Selim Geray Sultan’ın kızı) Fatma Sultan Hanı̂’nin 1875 yllından kısa bir müddet önce İstanbul'da Süleymaniye semtinde vefat ettiği zikredilmektedir. BOA, İrade-Şura-yı Devlet, Dosya no.: 29, Gömlek no.: 1397; MV, Defter no.: 8, Belge no.: 71; İrade-Dahiliye, Dosya no.: 698, Gömlek no.: 48869. 


\section{Maddi İzleri}

II. Meñli Geray Han'ın Tophane'de yaptırdığı Gülşenî tekkesi ise tekkelerin kapatıldığı 1925 yılından sonra ortadan kalkmış ve 1937'de arsası satılmıştır ${ }^{26}$.

\section{Saray/Tekirdağ}

Günümüzde Tekirdağ İli’ne bağlı bir ilçe merkezi olan Saray, Geray hanedanı mensuplarının en azından XVI. yüzyılın ikinci yarısından itibaren kesintisiz yaşadıkları ve dolayısıyla Rumeli'nde en erken dönemde yerleştikleri yerlerden biriydi. Geray sülalesi mensupları halen de Saray'da yaşamayı sürdürmektedirler. Gerayların Saray'da inşa ettirmiş oldukları eserlerin pek çoğunun kaydı günümüze gelmediği için bunların neler olduklarını bilemiyoruz. Muhakkak ki buradaki Geray hanedanı mensupları statülerine uygun şekilde saray yahut geniş konaklarda ikamet etmekteydi. Bunlardan yalnızca Arslan Geray Han'a ait olan bazılarının varlığının belgelerine sahibiz. Arslan Geray Han'ın Saray'da konağı yahut sarayı, bağı, bahçesi, hamamı ve su kanalları olup, bu mülkler bilâhare onun kurduğu vakfa devredilmişti ${ }^{27}$. Fransa'nın Kırım Hanlığı nezdindeki elçisi Macar asıllı François Baron de Tott'un (Tóth Ferenc) 1769 yılı başlarında ziyaret ve hatıralarında tasvir ettiği Gerayların buradaki sarayı Arslan Geray Han'nnki olmalıdır. Söz konusu saray kasabanın o zaman mevcut olan kalesinin dışında ve yerleşim yerlerinin merkezinde bulunmakta ve tipik olarak birçok yapıdan oluşmaktaydı. Baron de Tott'un ziyareti sırasında henüz Kırım Hanlığı'na getirilmiş olan genç IV. Devlet Geray Han'ın ikamet ettiği bölüm diğer yapılardan biraz uzakta olup geniş bir avluya sahipti ${ }^{28}$. Bu sarayın ne zaman ortadan kalktığı tespit edilememektedir. Bundan başka, Arslan Geray Han'ın kasabada ve çevresinde birçok çeşmeler de yaptırdığını bilmekteyiz ${ }^{29}$. Ancak, ne Arslan Geray Han'ın Saray’daki ikametgâhı ve müştemilâtı, ne de onun yaptırdığı çeşmelerden herhangi biri günümüze ulaşamamıştır.

Saray Kasabası, Geray hanedanı mensuplarının bugünkü Türkiye sınırları dahilinde en çok kabirlerinin bulunduğu yerdir. Dört Kırım Hanı (II. Devlet Geray

26 Devlet Arşivleri Başkanlı̆̆ı Cumhuriyet Arşivi (BCA) (Ankara), Sayı: 63082, Dosya no.: 299-127, Fon Kodu: 30.18.1.2, Yer no.: 73.26.13.

27 Hüseyin Çınar, “Arslan Giray Han ve Kırım'ın Yeniden İmârında Vakıfların Rolü”, Vakıflar Dergisi, Ankara, S. 30, (2007), s. 129.

28 François Baron de Tott [Tóth Ferenc], Memoirs of Baron De Tott, C I (Londra 1785), s. 228-229.

29 Halim Giray [Halim Geray Sultan], Gülbün-ï Hânân (Kirm Hanlan Tarihi). Değerlendirme-MetinTipkıbasım, Hazırlayanlar: Alper Başer-Alper Günaydın, İstanbul 2013, s. 95. 
Han, II. Fetih Geray Han, III. Selim Geray Han ve IV. Devlet Geray Han) ve bir Kuban Hanı (Şahbaz Geray Han) ile sayısı bilinmeyen Kalgay, Nureddin, Geray sultan, Geray hanedanının kadın mensupları ve Kırım Hanlığı'nın muhtelif idarecileri Saray'ın tam merkezinde yer alan Ayas Paşa Camii haziresine defnedilmişlerdi. Aynı zamanda Osmanlı ricalinden pek çok kişi de bu hazirede gömülüydü. Ne var ki, buradaki mezar taşlarının tamamı 27 Mayıs 1960 darbesini müteakip Saray Kasabası'na tayin edilen askerî mahallî yöneticinin emriyle yerinden söktürülerek şehir mezarlığına atılmıştır. Bu tarih katliamıyla paha biçilmez tarihî ve estetik önemi haiz mezar taşlarının bir kısmı ebediyen yok olmuş, büyük çoğunluğu parçalanmış, bazıları duvar malzemesi olarak kullanılmış, ancak bir kısmı uzun yılların uğraşlarıyla 1990'lı ve 2000'li yıllarda Ayas Paşa Camii haziresine geri getirilebilmiş, tabiatıyla defin yerleri tamamen karışmıştır. 1960’ların başındaki bu vandalizm dolayısıyla yok edilen mezar taşlarının hangileri olduğunu belirleyebilmek imkânsızdır. Yalnız, Prut Muharebesi kahramanı II. Devlet Geray Han’ın (ölümü 1725) ve Kuban Hanı Şahbaz Geray Han’ın (ölümü: 1793) mezar taşlarının da günümüzde ortadan kaybolmuş olanlar arasında olduğunu bilmekteyiz ${ }^{30}$. Fazlasıyla tahrip olmakla birlikte günümüzde Ayas Paşa Camii hazire alanına geri getirilebilmiş ve halen orada bulunan Geray hanedanına ait lahit ve mezar taşları şunlardır:

II. Fetih Geray Han (ölümü: Hicrî 22 Şaban 1159 [Milâdî 9 Eylül 1746])

III. Selim Geray Han (ölümü: Hicrî 1200 [Milâdî 1786])

IV. Devlet Geray Han (ölümü: Hicrî Ramazan 1194 [Milâdî Eylül 1780])

Safa Geray Sultan (Bahadır Geray Sultan’ın oğlu; ölümü: Hicrî 1102 [Milâdî 1690-1691])

İslâm Geray Sultan (II. Devlet Geray Han'ın oğlu; ölümü: Hicrî 1155 [Milâdî 1742-1743])

... (taşın bu kısmı kırıktır) Geray Sultan (Kırım Geray Han'ın oğlu; ölümü: Hicrî 1181 [Milâdî 1767-1768])

Kaplan Geray Sultan (ölümü: Hicrî 1183 [Milâdî 1769-1770] - baştaşında

"Geray" değil "Gerey" şeklinde yazılmıştır)

30 Ayas Paşa Camii haziresindeki mezar taşları daha 1940'ların başlarında hayli harap ve perişan bir durumdaydı. Ancak, en azından o sırada II. Devlet Geray Han'ın kabrinin mevcut olduğu bilinmektedir. Kemal Altan, "Meşhur (Kırım Giray)ların Mezarları, Akşsam, İstanbul 3 Temmuz 1941. O yıllarda, bu bilgiyi edinmemizi sağlayan tanınmış mimar Kemal Altan söz konusu mezar taşlarının bir ölçüde de olsa tamir ve düzenlemesini sağlamıştı. Mazhar Altan, "Mimar Kemal Altan”, Arkitekt, S. 199-200 (İstanbul 1948), s. 179. 


\section{Maddi İzleri}

İslâm Geray Sultan (ölümü: Hicrî 1186 [Milâdî 1772-1773])

Ali Geray Sultan (İslâm Geray Sultan’ın oğlu; ölümü: Hicrî 1208 [Milâdî 1793-1994])

Sahib Geray Sultan (IV. Devlet Geray Han’ın oğlu; ölümü: Hicrî 1218 [Milâdî 1803-1804])

Arslan Geray Han zâde Kalgay ... (İslâm Geray Sultan yahut Selim Geray Sultan'dan biri olmalıdır $)^{31}$

Nahife Sultan (Kalgay İslâm Geray Sultan zâde Arslan Geray Sultan'ın kızı; ölümü: Hicrî 5 Rebîyülâhir 1181 [Milâdî 31 Ağustos 1767])

Arslan Geray Han'ın kızı ... (ölümü: ?)

İslâm Geray Sultan’ın hanımı Fatma Hanım binti Mehmed Ağa (ölümü: ?)

Melekhan Hanım Beyzâde (Selim Geray Sultan’ın annesi ve Meñli Geray Bey’in kızı; ölümü: ?) ${ }^{32}$

... binti Arslan Geray ...

Cennethan Bikeç (ölümü: Hicrî 1153 [Milâdî 1740-1741])

Geraylara ait olması muhtemel Hicrî 28 Zilkade 1204 [Milâdî 9 Ağustos 1790] tarihli ismi kırılmış baştaşı

Geraylara ait olması muhtemel Hicrî 1 Cemâziyelevvel 1213 [Milâdî 11 Ekim 1798] tarihli ismi kırılmış baştaşı

Geraylara ait olması muhtemel Hicrî 1186 [Milâdî 1772-1773] tarihli ismi kırılmış baştaşı

Mehmed Geray Sultan 12.. (1203 olması gerekir; Şahbaz Geray Han’ın oğlu) (Şehit taşı $)^{33}$

31 Bu mezar taşında mevtanın isminin ve vefat tarihinin bulunduğu kısım kırıktır. Ancak sağlam kısımlarından onun Arslan Geray Han'ın oğlu olup kalgay mansıbında bulunduğu okunabilmektedir. Arslan Geray Han'ın kalgay olmuş olan diğer oğullarının defin yerleri bilindiğinden buradaki sâbık kalgay ancak İslâm Geray Geray Sultan veya Selim Geray Sultan'dan biri olabilir.

32 Burada adı geçen Meñli Geray Bey'in Geray hanedanından olduğu sanılmamalıdır. Geray hanedanının istisnasız bütün erkek mensupları eğer tahta çıkmışlarsa "Han", çlkmamışlarsa "Sultan" unvanını taşırlar ve adlarında asla "Bey" yahut başka bir unvanı taşımazlardı. Buna karşılık başta Şirin kabilesi olmak üzere hanlıktaki üst seviyedeki kabilelerin bey ve mirzaları (hanedan ismi olarak değil) özel isim olarak Geray adını kullanabilmekteydi. Bu bakımdan, adı geçen Meñli Geray Bey'in bu beylerden biri olduğu açıktır.

33 “24 yaşındayken şehit düşen ve Kavşan'da defnedilen Mehmed Geray Sultan”a ait olduğu yazılan bu şehit taşının tarih kısmı kırılmış olduğu için ancak "12.." ibaresi okunabilmektedir. Söz 
Selim Geray Sultan 1205 (Maksud Geray'ın oğlu) (Şehit taş1) ${ }^{34}$

Bunlar haricinde Saray Kasabası'nda Geraylardan kalabilen başka mimari iz yoktur.

\section{Karapürçek Köyü/Saray-Tekirdăg}

Saray’a bağlı Karapürçek Köyü’nü Edirköy’e bağlayan yolda, Vize Deresi üzerindeki tarihî köprü III. Selim Geray Han tarafindan yaptırılmış olup ${ }^{35}$, bugünkü Türkiye toprakları içinde Geray hanedanından kalabilen en büyük yapıyı teşkil etmektedir. Halen üç kemeri görünen köprünün diğer kemerleri toprak altında kalmış olduğundan, gerçekte kaç kemerli olduğu anlaşılmamaktadır. Köprünün açıktaki kısmının boyu yaklaşı 50 metredir. Köprü günümüzde de ayakta olmakla birlikte artık kullanılmamakta ve yol hemen yanına yapılan yeni köprüden geçmektedir. Definecilerin tahribatından kurtulamamış olan bu eserin tam ortasındaki parçaların noksanlığı, burada bulunması beklenen kitabenin çalınmış olabileceğini akla getirmektedir. Çevre sâkinleri Domino Köprüsü olarak da adlandırdıkları köprünün banisinden haberdar değillerdir.

\section{Edirköy/Saray-Tekirdağ}

Geray sülalesi mensuplarının 1930'lara kadar yaşayageldikleri Edirköy'deki köy mezarlığında Geray hanedanı mensuplarına ait yalnızca kırık bir mezar taşı kalabilmiştir. Mezar taşının sağlam kısmında müteveffiyenin "__med (Mehmed?/ Ahmed?) Geray Sultan’ın kızı Afife" Hanım olduğu okunabilmektedir. Buradaki Geraylara ait konak ise çoktan ortadan kalkmıştır.

\section{Hayrabolu/Tekirdağ}

Tekirdağ'ın Hayrabolu ilçe merkezi de Geray hanedanı mensuplarının yaşadıkları ve vefatlarında defnedildikleri önemli yerlerden biriydi. Kasabada kendisine ait bir saray bulunan Selâmet Geray Sultan, vefatından sonra Yahya Çavuş zaviyesine gömülmüş̧ü ${ }^{36}$. Selâmet Geray Sultan’ın sarayı günümüze ulaşamadığı gibi,

konusu şehit taşının 30 Aralık 1788'de (Hicrî 1 Rebîyülâhir 1203’te) Gangura Köyü yakınlarındaki muharebelerde şehit düşen ve Kavşan'da gömülen Şahbaz Geray Hanzâde Mehmed Geray Sultan'a ait olduğuna şüphe yoktur.

34 Bu Selim Geray Sultan, İsmail Kalesi'nin Rus ordusuna karşı savunmasında görev alan ve 22 Aralık 1790'da kale düştüğünde şehit edilen 6 Geray sultandan biriydi.

35 Halim Giray, Gülbün-ü Hânân, s. 101.

36 Caferzâde Mehmet Tevfik [Selen], Tarihte Hayrabolu ve Çevresi, Hazırlayan: Aydın Oy Tekirdă̆ 1989, s. 54. 


\section{Maddi İzleri}

onun defnedildiği Yahya Çavuş Zaviyesi de bütünüyle ortadan kalkmıştır ${ }^{37}$. Hayrabolu'da Kalgay Mübarek Geray Sultan'a ait 1770'lerin ortasında inşa edilmiş bir saray yahut konak da bulunmaktayd $1^{38}$. Ancak, bundan da geriye hiçbir şey kalmamıştır. Ayrıca, Âdil Geray Sultan ile Arslan Geray Han'ın oğulları olan Safa Geray Sultan ve Meñli Geray Sultan'ın Hayrabolu'daki Çarşı Camii yahut diğer adıyla Hasib Bey Camii haziresinde medfûn olduğu bilinmektedir ${ }^{39}$. Söz konusu Geray sultanlara ait mezar taşları günümüzde mevcut değildir. Günümüzde Hayrabolu'da yalnızca Paşa Camii olarak da bilinen Çelebi Sultan Mehmed Camii'nin doğu tarafina bitişik olan hazirede Geray hanedanı mensuplarına ait üç mezar taşı bulunmaktadır. Aslında bu üç Geray sultan buraya değil, günümüzde Atatürk heykelinin olduğu meydanın yerinde bulunan eski Osmanlı mezarlığına gömülmüşlerdi. 1950'li yıllarda bu mezarlık ortadan kaldııldığında bazı diğer mezar taşları ile birlikte Geraylara ait olanlar da Çelebi Sultan Mehmed Camii haziresine taşınmışıı ${ }^{40}$. Bu taşınma esnasında Geraylara ve başkalarına ait birçok kabrin ve mezar taşının kaybolduğuna muhakkak gözüyle bakılabilir. Çelebi Sultan Mehmed Camii haziresindeki mezar taşları 2000'li ylllara kadar gayet bakımsız ve dağınık bir haldeyken, bilâhare bir ölçüde düzene konulmuş, ancak mezarların asıl yerleri büyük ölçüde karışmıştır. Hatta mahallî tarihçi Şerif Baysalan'ın ifadesine göre, Geraylara ait mezar taşlarının birinin yazıları kasıtlı olarak kazınmıştr ${ }^{41}$. Çelebi Sultan Mehmed Camii haziresindeki Geraylara ait mezar taşları şunlardır:

37 Daha 1940'ların ilk yarısında Yahya Çavuş Zaviyesi tamamen ortadan kalkmış olduğu gibi, o tarihlerde Selâmet Geray Sultan’ın sarayının nerede olduğunu bilen kimse kalmamıştı. Rıfkı Melûl Meriç, "Trakya Kitabeleri, I. Hayrebolu Kitabeleri”, Tarih Vesikalar, Yeni Seri, c. I (Ístanbul), S. 2 (17) (Ocak 1958), s. 214-215.

38 [Hayrabolulu Hasîb], Hayrabolulu Hasîb Dî̀ânı, Hazırlayanlar: Ramazan Ekici-Suat Donuk, Ankara 2015, s. 105-106.

39 Caferzâde Mehmet Tevfik, s. 54. Burada adı geçen Âdil Geray Sultan Hayrabolu'nun Karabürçek Köyü’nde yaşayan Topal Ahmed Geray Sultan zâde Âdil Geray Sultan olabilir. Bununla birlikte, bir başka Âdil Geray Sultan da XVIII. yüzyıl başlarında Hayrabolu'nun Sarıyar Köyü'nde zeamet sahibiydi. BOA, Ali Emirî-Üçüncü Ahmed, Dosya no.: 139, Gömlek no.: 13514. Caferzâde Mehmed Tevfik Bey’in sözünü ettiği Arslan Geray Han zâde Safa Geray Sultan’ın kardeşi Kalgay Mübarek Geray Sultan’ın ölümünden (1789) daha önceki bir tarihte öldüğünü biliyoruz. BOA, Cevdet-Hariciye, Dosya no.: 118, Gömlek no.: 5886.

40 Şerif Baysalan, Gelmişi Geçmişi Bugünüyle Hayrabolu, Tekirdağ 2006, s. 42.

41 Şerif Baysalan, Gelmişi Geçmişi Bugünüyle Hayrabolu (Tekirdağ, 2006), s. 42. Saha araştırmamızda Baysalan’ın sözünü ettiği kazınmış olan bu mezar taşını bulamadık. 
Kalgay [Mübarek Geray Sultan] (Arslan Geray Han'ın oğlu, ölümü: Hicrî 1 Zilhicce 1203 [Milâdî 23 Ağustos 1789])

İnayet Geray Sultan (Arslan Geray Han zâde Kalgay Mübarek Geray Sultan'ın küçük oğlu, ölümü: Hicrî 1218 [Milâdî 1803-1804])

Nureddin İzzet Geray Sultan (Arslan Geray Han zâde Kalgay Mübarek Geray Sultan’ın oğlu, ölümü: Hicrî 1241 [Milâdî 1825-1826])

\section{Çakıllı Kasabası/Saray-Tekirdăg}

Halen Tekirdağ İli'nin Saray İlçesi'ne bağıı olan Çakıllı Beldesi Geray hanedanı mensuplarının XVIII. yüzyılın ilk yarısından itibaren yaşadıkları ve çiftliklerinin bulunduğu bir köydü². Çakıllı (II. Fetih Geray Han’n soyundan gelen) Geray hanedanı mensuplarının günümüze kadar kesintisiz olarak yaşamayı sürdürdükleri nadir yerleşim yerlerindendir. Gerayların Çakıllı'daki büyük konağı 1930'lara kadar ayaktayd ${ }^{43}$. Bu tarihten sonra harap olan konağın yıkıntılarının 1960'ların ortalarına kadar durduğu ve burasının 1970'lerde bir şekilde belediyeye geçtiği anlatılmaktadır. Günümüzde söz konusu konağın yerinde çay bahçesi bulunduğu gibi, Gerayların Çakıllı'daki çiftliğinden de hiçbir iz kalmamıştır. Buradaki caminin haziresinde 2012 baharma kadar mevcut olduğunu bildiğimiz ve üzerinde “... Gazi Han ruhuna fatiha. Sene 1185 [1771-1772]" ibareleri okunabilen ${ }^{44}$ kırı baştaşı aynı yılın yazında çalınmış durumdaydı.

\section{Paşaköy-Pınarbaşı Köyleri/Ergene-Tekirdağ}

Tekirdă̆’’n Ergene İlçesi’ne bağlı birbirine bitişik Paşaköy ve Pınarbaşı köyleri üzerinde bulunan büyük çiftlik Kırım'ın en büyük hanlarından biri kabul edilen Kırım Geray Han’a aitti. Kırım Geray Han’ı Pınarbaşı Çiftliği’nde büyük bir

42 Osmanlı-İran savaşında Fetih Geray Sultan'ın kumandasındaki Kırım hanlık ordusu Nadir Şah tarafindan kuşatılan Gence Kalesi'nin düşmesini önlediğinden, Fetih Geray Sultan’a Vize Sancağı has olarak verilmişti ki, Çakıllı da bu topraklar içindeydi. BOA, A.DVN.MHM.d., Defter no.: 149, s. 165, hüküm no.: 563. Fetih Geray Sultan 1736'da amcası I. Kaplan Geray'ın yerine Han (II. Fetih Geray Han) oldu.

43 Mete Esin, "Giraylar ve Vize", Kirm, S. 10, (Ankara Ocak-Şubat-Mart 1995), s. 23-24.

$44 \mathrm{Bu}$ mezar taşı 1990’ların ortalarında Nicole Kançal-Ferrari tarafindan tespit edilmiş ve fotoğraflanmıştı. Nicole Kançal, "Kırım Hanlarının İmar Faaliyeti ve Mezar Taşları", s. 82, resimler bölümü 77 numaralı fotoğraf. Bu tarihte ölen ve mezar taşı bilinmeyen bir Kırım Hanı olmadığından, "Gazi Han" ibaresinden önce bin (oğlu) veya binti (kızı) ibaresinin yer aldığı kanaatindeyiz. 


\section{Maddi İzleri}

saray ve güzel bir bahçe yaptırdığı bilinmektedir ${ }^{45}$. Gayet renkli bir kişiliği olan Kırım Geray Han'ın bu sarayı çok canlı bir sosyal hayatın merkezi hâline gelmiş, Mustafa Kesbî̀ye göre, gözden düşmüş Mısır beyleri, adalara sürgüne gönderilmiş sâbık devlet görevlileri, Gezayir kaptanları, Arnavut paşaları, Bosna kaptanları ve vezir çuhadarları gibi bir seferde sayıları beş yüzü geçen misafirlere ev sahipliği yapmıştı ${ }^{46}$. Bir zamanlar dillere destan olan bu saraydan hiçbir iz kalmadığı gibi, pek çok Geray sülalesi mensubunun defnedildiği Paşaköy Camii'nin haziresi de 1980’lerin başlarında dönemin kaymakamının emriyle yerlerinden söktürülüp bir kenara atılmıs, kalabilen mezar taşları ancak 2000’li yıllarda köy imamının şahsi gayretleriyle kısmen toplanarak beton üzerine dikilmişlerdir. Bu kurtulabilen mezar taşları arasında Geray hanedanı mensuplarına ait şunlar bulunmaktadır:

Selim Geray Sultan (Kırım Geray Han zâde Kuban Hanı Baht Geray Han’nn oğlu, ölümü: Hicrî Ramazan 1261 [Milâdî Eylül 1845])

Kayahan Sultan (ölümü: Hicrî 1204 [Milâdî 1789-1790])

Beyzâde Fatma Hatun (ölümü: Hicrî 18 Cemâziyelâhir 1231 [Milâdî 16 Mayıs 1816])

Pınarbaşı Çiftliği arazisinde (bugünkü Pınarbaşı Köyü dahilinde) bulunan ve görenlerce çok geniş olduğu anlatılan diğer tarihî mezarlık ise, 10 kadar kırık mezar taşı haricinde tamamen yok edilmiştir. Farklı yerlere atıldığı için günümüze kalabilen bu 10 kadar mezar taşı arasında Geray hanedanı mensuplarına ait olanlar bulunmamaktadır. Mezarlık arazisi üzerine pek çok evler kurulduğu gibi, 1986'da mezarlığın en geniş kısmında bulunan sayısız Osmanlı devri mezar taşları yakındaki bir su birikintisinin içine atılarak üzerlerine büyük miktarda toprak doldurulmuş, mezarlık ise buldozerlerle düzlenerek futbol sahası haline getirilmiştir.

\section{Çatalca/İstanbul}

Son Kırım hanlarından II. Sahib Geray Han tahttan indirildikten sonra Çatalca Kasabası'nda 28 yıl boyunca konağında hiç dışarı çıkmadan yaşamış ve ölümü sonrasinda kasabadaki Ferhad Paşa Camii'nin haziresine gömülmüş̧ü. Başka birçok Geray sülalesi mensubu da Çatalca Kasabası'nda ikamet etmiştir. Günümüzde Ferhad Paşa Camii haziresinde II. Sahib Geray Han'ın kabri mevcut değildir. Hazirede Geraylara ait şu mezar taşları günümüze gelebilmiştir:

45 Halim Giray, Gülbün-ü Hânân, s. 99.

46 Mustafa Kesbî, İbretnûmâ-yn Devlet (Tahlil ve Tenkitli Metin), Hazırlayan: Ahmet Öğreten, Ankara 2002, s. 73. 
İslâm Geray Sultan (Ahmed Geray Sultan’ın oğlu, ölümü: Hicrî 1228 [Milâdî 1813])

Mehmed Geray Sultan (Ahmed Geray Sultan’ın oğlu, ölümü: Hicrî 1227 [Milâdî 1812])

[Halim Geray Sultan] (Şahbaz Geray Han'ın oğlu, tarihçi, şair ve asker, tarih kısmı kırık) ${ }^{47}$

\section{Subaşı Kasabası/Çatalca-İstanbul}

Günümüzde İstanbul'un Çatalca İlçesi’ne bağlı bir belde olan Subaşı, en azından XVIII. yüzyıl başlarından itibaren Kırım hanlarının yaşadığı, çiftliklerinin bulunduğu ve pek çok mimarî eserlerle süsledikleri yerlerden biriydi. I. Kaplan Geray Han, II. Selim Geray Han ve II. Kaplan Geray Han ile II. Kaplan Geray Han'in oğlu Selim Geray Sultan burada yaşamıs, bu köyde sadece Kırım değil, Osmanlı tarihinin de bazı mühim olayları yaşanmışt ${ }^{48}$. Gerayların burada inşa ettirdikleri saray, hamam ve diğer yapılar bütün çevrede dikkat çekmekteydi. Selim Geray Sultan’ın kızı ve büyük nüfuza sahip bir kadın olarak tanınan Fatma Sultan Hanı̂’nin 1872 yahut 1873 yılındaki vefatından sonra Gerayların Subaşı'ndaki varlığı sona erdi. Bu tarihten itibaren Geraylara ait yapıların çoğu ve özellikle de saray yok olma sürecine girmiştir. Halen bu saraydan geriye kalabilen yegâne iz, fiilen hiçbir koruma altında olmayan ve özel bir mülkün içinde yer alan hamam kalıntısından ibarettir. Selim Geray Sultan (sonraki II. Selim Geray Han) tarafindan yaptırılan çeşme ise Subaşı'nın tarihî merkezinde yer alan Yazıcı Mustafa Çelebi Camiìne bitişik olarak hâlen ayaktadır. Bununla birlikte, çeşmenin Hicrî 1155 (Milâdî 17421743) tarihli kitabesi caminin haziresine atılmış durumda bulunmaktadır.

Söz konusu mezar taşının ad kısmı kırılarak kaybolmuş ise de, mevcut parçada medfun olan kişinin Şahbaz Geray Han'ın oğlu olduğu bilgisi okunabilmektedir. Nitekim, Halim Geray Sultan Kuban Hanı Şahbaz Geray Han'ın oğluydu. Zaten 1823'te Çatalca'da vefat eden Halim Geray Sultan'ın buraya defnedilmiş olduğu bilinmektedir. Bursalı Mehmed Tahir, İdare-i Osmaniyye Zamannda Yetişen Kirm Müellifleri, İstanbul 1919, s. 18.

48 XIX. yüzyılın ilk yıllarındaki yaygın eşkıyalık olayları sırasında Selim Geray Sultan'ın Subaşı’ndaki çiftliği de tehdit altına girmiş, hatta ona ait çevredeki Dokuzağaç Hanı ve Beylerce Çiftliği asi askerlerce ateşe verilmişti. BOA, HAT, Dosya no.: 36, Gömlek no.: 1841. Padişah III. Selim'in yararlıkları dolayısıyla 1807'de çuha kaplı samur kürk giydirdiği (BOA, Cevdet-Dahiliye, Dosya no.: 42, Dosya no.: 2061) Selim Geray Sultan, Sadrâzam Alemdar Mustafa Paşa'nın öldürüldügü Kasım 1808'deki yeniçeri isyanı sonrasında asilerin baş hedeflerinden Kapudan-ı Derya Kırımlı Abdullah Râmiz Paşa'nın ve Kadı Abdurrahman Paşa’nın kaçışında kritik rol oynamış ve Subaşı Çiftliği’nde sakladığı bu devlet adamlarını yeniçerilere teslim etmemiş̧i. Câbî Ömer Efendi, Câb̂̂ Tarihi, C I, Hazırlayan: Mehmet Ali Beyhan, Ankara 2003, s. 296-297. 


\section{Maddi İzleri}

Yazıcı Mustafa Çelebi Camii Gerayların köye yerleşmesinden önce inşa ettirilmiş olmakla birlikte, onların bu önemli ikametgâhlarındaki mabedi muhtelif zamanlarda tamir ettirdiklerine (belki de yeniden inşa ettirdiklerine) ve buraya büyük önem verdiklerine şüphe yoktur. Nitekim, aralarında bir Han'ın (II. Kaplan Geray Han) da bulunduğu çok sayıda Geray hanedanı mensubu bu caminin haziresine defnedilmiştir. Ancak, bu cami ve hazire de bilinçsizlikten ve bakımsızlıktan payını fazlasıyla almıştır. 1979 yılında bu tarihî cami aslına hiç uygun olmayan bir şekilde yeniden inşa edilmiş, bu sırada haziredeki son derece önemli mezar taşlarının pek çoğu darmadağın edilmiş, toprağa gömülmüş, parçalanmış veya bütünüyle yok edilmiştir ${ }^{49}$. Haziredeki tahribat, caminin daha sonraki, özellikle 1988'deki "tamir" ve düzenlemelerden sonra da devam edegelmiştir. Müteakip yllarda da cami ve çevresinde yapılan tamirler hazireyi ve caminin orijinal özelliklerini pek az dikkate alır şekilde yürütülmüştür. 2019-2020 yaz aylarında yapılan çalı̧̧malarda ise hazirenin arka kısmındaki yığılma topraklar temizlenmiş, toprak altında bazı mezar taşları çıkarılmış ve mezar taşları numaralandırılmıştır. Bununla birlikte, 2021 yazı itibarıyla mevcut mezar taşlarının çoğu yatık olarak istif edilmiş durumdaydı. Cami haziresindeki Geray hanedanı mensuplarına ait günümüze ulaşabilen kabir ve mezar taşları şunlardan ibarettir:

II. Kaplan Geray Han (ölümü: Hicrî Rebîyülâhir 1185 [Milâdî TemmuzAğustos 1771])

Selim Geray Sultan (II. Kaplan Geray Han'ın oğlu, ölümü: Hicrî 27 Ramazan 1233 [Milâdî 31 Temmuz 1818])

Ferah Sultan (II. Kaplan Geray Han’n kızı, ölümü: Hicrî 1238 [Milâdî 1822-1823])

Halim Geray Sultan (III. Selim Geray Han’nn oğlu, ölümü: Hicrî 1256 [Milâdî 1840-1841] $)^{50}$

49 1979'daki inşaat sırasında yok edilen kabirlerin hangileri olduğunu tespit edebilmek mümkün değildir. 1970'de bu hazireyi ziyaret eden Reşat Ekrem Koçu, Hicrî 1185 'te (Milâdî 1771-1772) vefat eden Fatma Sultan Hanı̂’nin (ondan tam bir asır sonra vefat eden aynı isimdeki ve Selim Geray Sultan’ın kızı olan tanınmış hanım sultan ile karıştırılmamalıdır) halen mevcut olmayan kabrinden söz etmektedir. Reşat Ekrem Koçu, "Çatalca Sarayları", Tercüman (İstanbul), 23-24 Şubat 1970. Bu şekilde ortadan kaybolan başka pek çok mezar taşı olduğuna hiç şüphe yoktur.

50 Yazıcı Mustafa Çelebi Camii haziresinde Temmuz 2021'de yaptığımız son araştırmamızda parçalanmış olan bu baştaşının yalnızca Halim Geray Sultan'ın adının geçtiği üst kısmını bulabildik. Reşat Ekrem Koçu 1970 yılında söz konusu baştaşının üç parçasını görerek birleştirmiş ve bir fotoğrafını yayınlamıştı. Halim Geray Sultan'ın babasının kim olduğunu ve ölüm yılını Koçu'nun bu yazısından ve fotoğrafindan öğrenmekteyiz. Reşat Ekrem Koçu, 
Cennethan Bikeç (Kırık, tarih yok)

Hatice Bikeç (ölümü: Hicrî 1170 [Milâdî 1756-1757])

Fatma Bikeç (ölümü: Hicrî 1 Muharrem 1185 [Milâdî 16 Nisan 1771])

Naime Bikeç (ölümü: Hicrî Hicrî 7 Safer 1206 [Milâdî 6 Ekim 1791])

Sahib Sultan Hanî (ölümü: Muharrem 1185 [Milâdî Nisan/Mayıs 1771])

Hazirede mezar taşları bulunan diğer birçok kadınların da Geray hanedanı ile ilgili olması çok muhtemeldir. Ancak onların mezar taşı kitabelerinde bunun kesin karineleri görünmediğinden adlarını yukarıdaki listeye koymadık. Kırık olan pek çok mezar taşı ve lahit parçalarının ise kime ait olduğu tespit edilememektedir.

\section{Oklalı Köyü/Çatalca-İstanbul}

İstanbul İli’nin Çatalca İlçesi’ne bağlı olup Subaşı Köyü'ne sadece 2 km mesafede bulunan Oklalı Köyü’nde II. Kaplan Geray Han zâde Selim Geray Sultan'ın kızı Fatma Sultan Hanî tarafindan yaptırılmış bir çeşme bulunmaktaydı. Ancak bu çeşme XX. yüzyılın sonlarında adım adım yanındaki caminin yanında kaybedilmiştir. 1990'larda caminin abdest alma yeri haline gelen ve kapalı bir mekân içine alınan çeşmenin yalnızca kitabesi yerinde kalmıştı. 2012'de çeşmenin bir zamanlar bulunduğu şimdiki kapalı mekânın gasılhaneye dönüştürüldüğünü tespit ettik. Gasılhanenin iç duvarında bulunan mermer kitabe ise, 2021 yılı yaz ayları itibarıyla aynı yerde ve gayet dağınık bir ortamda mevcudiyeti zorlukla farkedilebilir haldeydi. Kitabenin 11 satırlık manzum metninde, çeşmenin Hicrî 1267 [Milâdî 1850-1851] tarihinde Fatma Sultan Hanî tarafından inşa ettirilmiş olduğu belirtilmektedir $^{51}$.

\section{Çorlu/Tekirdağ}

Tekirdağ’’n Çorlu ilçe merkezinde Geraylara ait yegâne kalıntı Fatih Camii haziresinde bulunan Kuban Hanı Baht Geray Han’ın büyük oğlu Kırım Geray Sul-

"Çatalca Sarayları", Tercüman, İstanbul 24 Şubat 1970.

51 Kitabede çeşmenin banîsinin Fatma Sultan olduğu ve onun Selim Geray Han soyundan geldiği belirtilmektedir. Burada sözü edilenin Subaşı Köyü’nde yaşayan Fatma Sultan Hanî olduğuna hiç şüphe etmemekteyiz. II. Kaplan Geray zâde Selim Geray Sultan'ın kızı olan Fatma Sultan Hanî, bu bakımdan II. Selim Geray Han’ın da torununun kızıydı. Subaşı Köyü Oklalı Köyü’ne komşu olduğu gibi, Fatma Sultan'ın Oklalı ile yakın ilişkileri bulunduğu da bilinmektedir. 1743'de Kırım Hanı olmasından önce Subaşı Köyü’nde ikamet eden II. Selim Geray Han (tahta çımadan önceki unvanıyla, Selim Geray Sultan) tarafindan Oklalı'da yaptırılmış olan ilk çeşmeyi Fatma Sultan Hanî’nin ihya veya tamir ettirilmiş olduğu kanaatindeyiz. 


\section{Maddi İzleri}

tan'ın kabridir. 1805 'te eşkıyalarla çarpışırken şehit düşen ${ }^{52}$ Kırım Geray Sultan'ın gayet süslü olan mezar taşı sağlam ise de, görkemli lahdi kırılmıştır. Aynı hazirede kabri bulunan Kırımlı Osman Efendi'nin kızı Fatma Hanım'ın da Geray hanedanı gelinlerinden olmasını muhtemel görmekteyiz ${ }^{53}$.

\section{Vize/Kirklareli}

Kırklareli'nin Vize ilçe merkezinde Geraylardan günümüze gelebilen yegâne maddi hatıra halen Vize Merkez Bağlar Mezarlığı'nda bulunan Mahmud Geray Sultan'a ait olup, Hicrî 1200 (Milâdî 1785-1786) tarihini taşıyan mezar taşıdır ${ }^{54}$. Bundan başka, yakın geçmişe kadar Vize'nin Bulaca Mahallesi'nde Bağlar Caddesi üzerinde II. Fetih Geray Han'ın kızı Sahib Sultan Hanı̂’nin yaptırdığı ve halk arasında "Sultan Çeşme" olarak bilinen bir çeşme bulunmaktaydı. Çeşmenin günümüze ulaşabilen gravüründe, atlı adam figürlü bir antik kabartma ile yine antik bir sütün kaidesinin devşirme malzeme olarak kullanıldığı görülmekteydi. Sultan Çeşme 1983 yahut 1984 yllında yol inşaatı gerekçesiyle geride hiçbir iz kalmayacak şekilde ortadan kaldırıldı.

\section{Kurklareli}

II. Fetih Geray Han'ın kızı Sahib Sultan Hanî’nin Hicrî 1183 (Milâdî 1769-1770) tarihli mezar taşı halen Kırklareli Müzesi’nde bulunmaktadır. Bu mezar taşının Vize'deki Ayasofya Camii'nin haziresinden getirilmiş olduğu söylenmektedir.

\section{Pinarhisar/Kirklareli}

Kırklareli'nin Pınarhisar ilçe merkezi de Gerayların ikamet ettiği önemli kasabalardan biriydi. Burada onlardan kalabilen maddi izler Hundî Hatun Camii'nin avlusunda bulunan şu iki mezar taşından ibarettir:

52 BOA, HAT, Dosya no.: 56, Gömlek no.: 2567.

53 Fatma Hanım'ın gayet süslü ve kaliteli mermerden yapılmış lahdinin üzerindeki baştaşı kitabesinde onun Geraylarla olan bağlantısından söz edilmemektedir. Bununla birlikte, Nicole Kançal-Ferrari gibi (Nicole Kançal, "Kırım Hanlarının İmar Faaliyeti ve Mezar Taşları”, s. 142143) biz de mezar taşının ve lahdinin mahiyetine bakarak onun Geraylardan birisinin hanımı olduğu kanaatindeyiz.

54 Babaannesi Çakıllı Kasabası’ndaki Geraylardan olan ve 2012 itibarıyla Vize'de yaşayan Mehmet Gökalp'in (1946 Vize doğumlu) ifadesine göre, günümüzde Vize Merkez Bağlar mezarlı̆̆ında bulunan bu mermer ve görkemli baştaşı aslında eski Kale Mahallesi’nde (şimdiki Mimar Sinan Mahallesi) bulunmaktaydı. Ancak, bu mezarlığın ortadan kaldırılması üzerine söz konusu baştaşı oradan taşınarak Bağlar Mezarlığı'nın girişine konulmuştur. 
Selâmet Geray Sultan (ölümü: Hicrî 1181 [Milâdî 1767-1768])

Batır [Bahadır] Geray Sultan (ölümü: Hicrî 1183 [Milâdî 1769-1770])55

Orijinalinin XV. asır yapısı olduğu tahmin edilen Hundî Hatun Camii bilâhare yıkıntı haline geldikten sonra, 1962'de genişletilerek yeniden inşa edilmiştir. Bu bakımdan, gerek genişletme ve yeniden inşa sırasında, gerekse ondan önceki tahribat dönemlerinde birtakım mezar ve mezar taşlarının, şu cümleden Geraylara ait olanların zarar görmüş ve ortadan kalkmış olması çok muhtemeldir. Nitekim, Semavi Eyice (belirtmediği bir tarihte) Pınarhisar'daki tamamen tahrip edilmiş olan Türk mezarlığının taşları arasında Geray hanedanı mensubu bir hanıma ait olan mermerden sanduka biçimli bir taş bulduklarını nakletmektedir ${ }^{56}$. Bu örneğe bakarak, Pınarhisar'da Gerayların yalnızca Hundî Hatun Camii haziresine değil, günümüze ulaşamayan başka mezarlıklara da defnedildikleri söylenebilir.

\section{Evrensekiz Köyü/Lüleburgaz-Kırklareli}

Geray hanedanı mensuplarının yaşamış olduğu Kırklareli’nin Lüleburgaz İlçesi’ne bağlı Evrensekiz (asıl adı: Örenseki) Köyü’nde üç Geray kızına, bir bikeçe (Geray cariyesine) ve bir de bir Geray sultana mı yahut Geray kızına mı ait olduğu açık olmayan toplam beş mezar taşı bulunmaktadır. Söz konusu mezar taşları Evrensekiz'in tarihî merkezindeki (bugünkü kasabanın Fatih Mahallesi'ndeki) eski köy camisinin dağılmış olan haziresinde bulunmuştur. Eski köy camisi 1967'de tamamen yıkılıp yeniden inşa edildiğinden, başka mezar taşlarının bu sırada yok olması muhtemeldir ${ }^{57}$. Evrensekiz Fatih Mahallesi Camii haziresindeki Geray hanedanı mensuplarına ait mevcut mezar taşları şunlardır:

Fatma Sultan (Ahmed Geray Sultan'ın kızı, ölümü 1181 [Milâdî 17671768])

Ayşe Bikeç (ölümü: Hicrî 1181 [Milâdî 1767-1768])

55 Bu iki mezar taşı hakkında yayın yapılmış, ancak Batır ismi sehven "Başar" olarak okunmuştur. Mustafa Özer, "Pınarhisar Çevresindeki Osmanlı Dönemi Yapıları", Yöre, S. 86-87, (Edirne Mayıs-Haziran-Temmuz 2007), s. 45-46.

56 İlginç bir şekilde, taşı üzerindeki yazı ters olup, ancak bir aynaya yansıtıldığında okunabilmekteydi ki, Eyice'nin tahminine göre bu durum iyi bir hattata yazdırılmış olan kitabe şablonunun okuma bilmeyen bir taşçı ustası tarafindan tersten kullanılması neticesi meydana gelmişti. Semavi Eyice, "Mezarlıklar ve Hazireler", İslâm Dünyasinda Mezarlklar ve Defin Gelenekleri, C I, Ankara, 1996, s. 127.

57 Evrensekiz'deki mezar taşlarına dikkatimizi çeken ve konuya ilişkin bilgilerinden yararlandığımız mahallî araştırmacı Mustafa Gültekin'e teşekkür ederiz. 


\section{Maddi İzleri}

Ferah Sultan Hanî (ölümü: Hicrî 1181 [Milâdî 1767-1768])

Şah Sultan (ölümü: 1186 [Milâdî 1772-1773])

... Sultan (ölümü: Hicrî 1181 [Milâdî 1767-1768])

\section{Edirne}

Sadece Gerayların izleri itibarıla değil, genel Türkiye (Osmanlı) tarihi itibarıyla da çok önemli tarihî mezar taşlarının kütle halinde yok edildiği bir diğer vaka da Edirne'de bir zamanlar var olan "Tatarhanîler" mezarlığının ortadan kaldırılmasıdır. Adının düşündüreceğinin aksine, bu mezarlığın Kırım hanları ile doğrudan bir ilgisi yoktur ${ }^{58}$. Bununla birlikte, kuruluşu en azından XIV. asra giden Tatarhanîler Mezarlığı'na XVII. yüzyıl ve sonrasında Geray hanedanı mensubu birçok kimsenin gömülmüş olmasını çok muhtemel görmekteyiz. Her halükârda, son derece geniş olan bu mezarlık Osmanlı devrine ait sayısız önemli şahsın gömüldüğü, çok büyük tarihî kıymeti haiz bir yerdi. Ne var ki, 1937'de Tatarhanîler Mezarlı̆̆ı'nın taşları tamamen söktürülerek yok edilmiş, yerine de Şehir Stadyumu ve

58 Tatarhanîler Mezarlığı’nın geçmişine ilişkin bilgilerimiz açık değildir. Bu mezarlı̆̆ı XVII. yüzyıl ortalarında görmüş olan Evliya Çelebi burayı "Tatar Hanlar ziyaretgâhı" olarak zikretmekte ve bir "Tatar Hanı"nın buraya gömülmüş olduğundan söz etmektedir. Evliya Çelebi, Evliyâ Çelebi Seyahatnâmesi, III. Kitap Hazırlayanlar: Seyit Ali Kahraman-Yücel Dağlı, İstanbul 1999, s. 266. Evliya Çelebi’nin ifadelerinden burasının geçmişinin, bilinmeyen kadim bir zamana yani ünlü seyyahın devrinden en azından birkaç yüzyıl evveline dayandığı anlaşılmaktadır. Elbette ki, bu kadar eski bir tarihte herhangi bir Kırım Hanı'nın buraya gömülmüş olması imkân haricidir. Mezarlığın geçmişi Kırım Hanlığı’nın teşekkülü öncesine yani XV. yüzyıl başlarına uzandığından, buranın Emir Timur'un Altın Orda Devleti'ni istilâsı sırasında Rumeli topraklarına iltica etmek zorunda kalan Altın Orda terkibinden "Tatar" cemaatleriyle, özellikle de onların reisleri Aktav ile ilişkili olduğu bellidir. Altın Orda Hanı Toktamış Han’ın önde gelen kumandanlarından olan olan Emir Aktav, Toktamış Han ile birlikte Timur'a karşı savaşmış, ancak mağlup olunca peşindeki düşman kuvvetlerinden zorlukla kurtularak 1398'de Osmanlı hakimiyetindeki Rumeli'ne sığınmıştı. Emir Aktav'ın macerası için, bakınız, Aurel Decei, "Etablissement de Aktav de la Horde d'Or dans l'Empire Ottoman, au temps de Yıldırım Bayezid”, 60. Doğum Yil Münasebetiyle Zeki Velidi Togan'a Armağan (İstanbul, 1950-1955), s. 77-92. Bilâhare Osmanlı hizmetine giren Emir Aktav Edirne'ye yerleştirilmişti. Ancak sonradan Sultan I. Bayezid'in (Yıldırım) kendisinden şüphelenmesi üzerine Edirne'de bir ziyafette zehirlenerek öldürülmüştü. İbn Kemal'in ifadesiyle, "şehrin [Edirne'nin] kenarında defn ettiler, meşhedi ol diyarda meşhur oldu". İbn Kemal (Kemalpaşazâde), Tevârih-i Âl-i Osman. IV. Defter, Hazırlayan: Koji Imazawa, Ankara 2000, s. $327-$ 343; Oruç Beğ, Oruç Bĕg Tarihi, Hazırlayan: Atsız, İstanbul t.y. [1972], s. 59-60. Bu bakımdan, Emir Aktav'ın buraya gömüldügüne ve söz konusu mezarlığın Emir Aktav ve maiyyetindekilere ilişkin olarak "Tatarhanîler" adını almış olduğuna şüphe etmemekteyiz. Emir Aktav elbette ki ne Altın Orda'nın, ne de Kırım'ın hanı idi. Mezarlığın adının sadece "Tatarlar" ile değil "Tatar hanları" ile ilişkilendirilmiş olması zaman içinde halk arasında oluşan bir yakıştırmadan ibaret olmalidir. 
elektrik fabrikası kurdurulmuştur ${ }^{59}$. Tatarhanîler mezarlığından sökülen Osmanlı mezar taşlarının bir kısmının Edirne'nin Selimiye, Üçşerefeli, Beylerbeyi ve Muradiye gibi bazı camilerinin avlularına yığıldığı, bir kısmının Edirne Müzesi önündeki mezar taşları açık sergi alanında (lapidaryumda) bulunduğu söylenmekte, çok daha az bir kısmının da eski mezarlık alanında kurulan ve şimdi yıkıntı halindeki eski elektrik fabrikasının önünde toprak altından çıkarılmış olarak sergilendiği görülmektedir. Tatarhanîler mezarlığındaki mezar taşlarının ne kadarının yok edildiği hiçbir zaman bilinemeyecektir. Sözünü ettiğimiz diğger yerlere dağılmış bulunan "kurtarılmış" mezar taşlarını ise oralara ait zaten mevcut olan diğer mezar taşlarından ayırt etmek elbette ki mümkün değildir. Gerek bu cami hazirelerinde ve sergi alanında yaptı̆̆ımız saha çalışmalarında, gerekse buralara ilişkin yayınlarda Geray hanedanı mensubu erkeklere ait herhangi bir mezar taşına yahut kitabeye rastlamadık. Bununla birlikte, Edirne'de hanedanın kadın mensuplarından iki kişinin mezar taşını tespit edebildik. Bunlar şunlardır:

Üç Şerefeli Cami haziresinde:

Rukiye Hanım (Arslan Geray Sultan’ın kızı, ölümü Hicrî 1246 [Milâdî 1830-1831]).

Zehrimar Mescidi haziresinde:

Ümmî Sultan (Numan Geray Sultan’nn kızı, ölümü Hicrî 1209 [Milâdî 1794-1795]).

\section{Çeşme/İzmir}

Üç defa Kırım tahtına çıkmış olan I. Kaplan Geray Han son saltanatından sonra Sakız Adası'nda ikamete memur edilmişti. Ekim yahut Kasım 1737'de bu adada vefat eden sâbık han vasiyeti üzerine Sakız’n karşısındaki Çeşme Kasabası'na nakledilerek Muallimhane-i Sıbyân haziresinde defnedildi ${ }^{60}$. Muallimhane-i Sıbyân haziresi XIX. yüzyılda buraya inşa edilen Hacı Memiş Ağa Medresesi'nin altında kaldı. I. Kaplan Geray Han’ın mezarı ise bu medrese inşaatı esnasında Osmanlı dönemi hükûmet konağının arkasındaki mezarlığa nakledildi. I. Kaplan

59 Necdet İşli, "Tatarhaniler yahut Zindan Altı Mezarlığı”, Arkitekt, S. 433 (İstanbul 1996), s. 48-49. Necdet İşli kendisiyle 31 Aralık 201 l'de İstanbul'da yaptığımız görüşmemizde, dönemin Trakya Umumî Müfettişi General Kâzım Dirik'in “Edirne'de çok fazla mezarlık bulunduğu ve bunların şehri çirkin gösterdiği”” gerekçesiyle mezarlığın ortadan kaldırılması emrini verdiğini duyduğunu söylemiştir.

60 Halim Giray, Gülbün-ü Hânân, s. 82. 


\section{Maddi İzleri}

Geray Han'ın buradaki mezarı kasaba sâkinlerinin yeteri kadar dikkatini çekmiş olmalıdır ki, burada bir "Tatar Hanı"nın medfun olduğu anlatılmakta, hatta buraya "Tatar Mezarlı̆̆ı" adı verilmekteydi ${ }^{61}$. Ne var ki, bu mezarlık 1938'de ortadan kaldırıldı. Hükûmet konağı da yok edilip yerine bir çarşı (Hulusi Öztin Çarşısı) inşa edildi. Söz konusu mezarlıktaki bir kısım mezartaşları Çeşme büyük mezarlığına yığılmışken, 1994’te Ege Üniversitesi öğretim görevlilerinden Aydoğan Demir başkanlığında bir heyet tarafindan yürütülen "İzmir-Çeşme Mezarlığı Araştırma ve İnceleme Çalışmaları" sırasında I. Kaplan Geray Han'ın (ölümü: Hicrî Receb 1150 [Milâdî Ekim-Kasım 1737]) baştaşı da bulundu' ${ }^{62}$. Han'ın mezar taşı günümüzde Çeşme Kalesi Müzesi’nde sergilenmektedir.

\section{Bursa}

XX. yüzyıl öncesi itibarıla Anadolu toprakları üzerinde Geray sülalesi mensuplarından kalabilmiş az sayıda maddi izlerden biri Bursa'daki Abdal Murad Camii haziresinde medfun bulunan İzzet Geray Sultan’nn (ölümü: 1312 [Milâdî 18941895]) kabridir. Kaplan Geray Sultan'n oğlu olan İzzet Geray Sultan İslimye'nin Buhalı (Bulgarca adı: Bikovo) Köyü’nde ikamet etmekteydi' ${ }^{63}$. 93 Harbi (18771878 Osmanlı-Rus Savaşı) sonrasında Bursa'ya hicret etmek zorunda kalmıştı. İzzet Geray Sultan'ın iyi durumdaki bu mezar taşından onun Bektaşî tarikati mensubu olduğu da anlaşılmaktadır.

\section{Kuzey Kafkasya'dan Göç Eden Geraylar ve Onların Anadolu'daki Bazı İzleri}

Pek çok Geray Sultan XVIII. yüzyılda Kırım Hanlığı’nın yıkılma süreci içinde Kuzey Kafkasya'da Adıge kabilelerinin arasına yerleşmişti. Bunların ahfâdı olan Gerayların önemli bir kısmı Adıge topluluklarının XIX. yüzyılda Osmanlı Devleti'ne göçleri esnasında içinde yaşadıkları kabilelerle birlikte Anadolu'ya iskân olundular. Bu Geraylardan bazılarının kabirleri günümüze kadar korunabilmiştir. Bunlardan biri Bursa'nın Karacabey İlçesi’ne bağlı Ulubat Köyü’nün eski mezarlı̆̆ında ${ }^{64}$ medfun olan "Hanzâde Salat [Selâmet] Geray zâde Şahin [Geray]"a

61 Aydoğan Demir, "I. Kaplan Giray Han’ın Mezar Taş», Tarih ve Toplum, S. 136 (İstanbul Nisan 1995), s. 25.

62 Aydoğan Demir, “I. Kaplan Giray Han’ın Mezar Taşı”, s. 25-26.

63 BOA, MVL, Dosya no.: 50, Gömlek no.: 50.

64 Söz konusu eski köy mezarlığı halen Sütaş Süt Fabrikası sınırları dahilinde kalmış durumdadır. 
aittir. Müteveffanın ölüm tarihi Hicrî Şevval 1317 [Milâdî Şubat 1900] olarak gösterilmektedir ${ }^{65}$.

Samsun'un Çarşamba İlçesi’ne bağlı olup Adıge muhacirlerle meskûn olan Melik Köyü'nde de Geray sülalesinin kadın mensuplarından birinin kabri bulunmaktadır. Orijinal mezar taşı ortadan kalkmıs olan Nefise adındaki bu hanımın muhtemelen 1960'larda yaptırılan yeni mezar taşında onun "Kırım Hanı'nın kızı" ve Şanuk Ahmed Bey'in hanımı olduğu kaydedilmiştir. XIX. yüzyıl ortalarında köyde yaşadığını bildiğimiz Şanuk Ahmed Bey Adıgelerin Şapsığ kolunun Şeretlok kabilesi beylerinden olup, Osmanlı Devleti'nde "Alay Beyi" rütbesini taşımaktaydı. Nefise Hanım'n herhangi bir Kırım Hanı'nın kızı olması söz konusu değilse de, bu ibarelerden onun Geray hanedanına mensup olduğu anlaşılmaktadır.

Yine Adıgeler arasında yaşamaktayken XIX. yüzyllın ikinci yarısında onlarla birlikte Osmanlı Devleti'ne göç etmiş bir başka Geray kolunun izlerine de Tokat'ın Zile İlçesi'ne bağlı Güzelbeyli (asıl adı: Silis) Kasabası'nda rastlanmaktadır. Silis'e yerleşen Geray sülalesi mensubu Meñli Geray Sultan zâde Han Geray (Adıge telaffuzuyla: Han Geri) Sultan’dı. Gerayların Güzelbeyli’deki ne zaman inşa edildiği bilinmeyen konağı, 2013 yılı itibarıyla harap halde ve yıkılma tehlikesi altında bulunmakla birlikte ayaktaydı ${ }^{66}$. Konağın yakınında bulunan ve yine Gerayların yaptırdığı çeşme ise büyük ölçüde tahrip olmuştu. Silis'e yerleşen Han Geray'mn kabri günümüze ulaşamamışsa da, onun 1932'de vefat eden oğlu Zekeriya Geray'ın mezarı Güzelbeyli (Silis) köy mezarlığındadır ${ }^{67}$.

Geray sülalesine ait olup İstanbul'da belirleyebildiğimiz kabirler meyanında yukarıda zikrettiğimiz Kılıç Ali Paşa Camii haziresinde medfun Saadet Geray Sultan (Sultan Sagat Geray) zâde Hanife Haniye Hanım da Gerayların Kafkasya'ya

65 Burada baştaşını zikrettiğimiz Şahin Geray, yine Ulubat Köyü’nde yaşamış Mehmed Geray Sultan zâde Şahin Geray Sultan (vefat tarihi: 1854 yahut 1855) ve (en azından 1910'da hayatta olduğunu bildiğimiz) Osmanlı ordusunda kaymakam (yarbay) rütbesinde görev yapmış olan Şahin Geray ile karıştırılmamalıdır.

66 1968'den beri içinde kimsenin yaşamadığı konağın bazı odaları yıkılmış, tahtaları ise ciddî derecede çürümüş durumdaydı. Zile şehir merkezinde yer alan ve "Gerayların konağı" olarak bilinen bir başka konak ise aslında Geraylara ait değildir. Restore edilmiş bulunan söz konusu konak Han Geray'ın aynı adı taşıyan torunu Hangeri Giray'ın ikinci karısı olan Şaziye Hanım'ın babası Bahri Bey'in konağı olup, Hangeri Bey'e varisi olmayan kaynatasından miras olarak kalmıştır.

67 Zekeriya Geray'ın hem Arap hem de Latin harfleriyle yazılan baştaşında "Han zâde Zekeriya Bey" ibaresi yer aldığı gibi, taşın üzerinde Kırım hanlarının ve Kırım Tatarlarının sembolü olan bir "Tarak Tamga" (Taraq Tamğa) yer almaktadır. 


\section{Maddi İzleri}

yerleşmiş koluna mensuptu. Hanife Haniye Hanım, Adıge aydınlanmasının öncü isimlerinden kabul edilen Mehmed Geray Sultan zâde Sultan Han Geray'ın da yeğeniydi.

\section{Bugünkü Bulgaristan Sınırları Dahilinde Kalan Maddi İzler}

Geray hanedanı mensuplarının Osmanlı Devleti'ndeki çiftlik ve ikametgâhlarının büyük çoğunluğu İslimye, Yeni Zağra, Eski Zağra, Yanbolu, Karinâbâd, Aydos, Ahyolu Burgazı ve Şumnu kazâlarında, yani bugünkü Bulgaristan sınırları içinde bulunmaktaydı. Bu geniş arazide, Geraylara ait veya onlarca inşa ettirildiği bilinen pek çok saray, konak, cami, hamam, köprü, değirmen ve çeşme bulunduğu gibi, sayısız Geray'ın mezarı (dolayısıyla mezar taşları ve lahitleri) da vardı. Bunlardan kayıtları günümüze ulaşmayan büyük kısmının neler oldukları hiçbir zaman bilinemeyecektir. Ancak, bazılarının geçmişteki varlığından haberdarız. 1667'de Yanbolu'yu ziyaret eden Evliya Çelebi, orada görüştüğü Kırım Geray Sultan'ın bu kasabadaki sarayını "pâdişâhâne bir sarây-ı cihân-nümâ" olarak tasvir etmektedir ${ }^{68}$. Kırım Geray Sultan'ın sarayının kaderi belli değildir ${ }^{69}$. Ancak, muhakkak ki diğer Gerayların da Yanbolu'da az-çok benzer ihtişamda ikametgâhları vardı. 1768 ve 1771-1772 tarihlerinde Kırım tahtında bulunan Maksud Geray Han Yanbolu Kazası'na bağlı Fındıklı Köyü’nde ikamet etmişti. Ancak, onun Yanbolu'nun içinde bazı çeşmeler inşa ettirdiği bilinmektedir ${ }^{70}$. Yanbolu'nun İkramşah Mahallesi’nde 1850’lerin ikinci yarısında banisi Halid Geray Sultan kızı Habibe Hanım'ın adını taşıyan bir zaviye bulunmaktaydı ${ }^{71}$. Gerayların yoğun olarak yaşadıkları İslimye, Eski Zağra, Yeni Zağra, Karinâbâd ve Aydos gibi kasabalarda ve bunlara bağlı köylerde pek çok benzer yapılar inşa ettirmiş olduklarına şüphe edilemez ${ }^{72}$.

68 Evliya Çelebi, Evliyâ Çelebi Seyahatnâmesi, VIII. Kitap, Hazırlayanlar: Seyit Ali Kahraman-Yücel Dağlı-Robert Dankoff, İstanbul 2003, s. 25-26.

69 Yanbolu Şehri'nde mahallî tarihçi Harlambi Bayev'in Gerayların sarayına ait olduğunu tahmin ettiği duvar kalıntıları bulunmaktadır. Haralambi Bayev, "Zagadıçni ruini nasred Yambol ili dvoretsit, koyto ne zavelyazvame", Vreme (Yanbolu), S. 11 (824) (9-15 Nisan 2015), s. 7. Ancak, Bayev'in de kabul ettiği üzere, ne bu kalıntıların, ne de söz konusu mevkinin Gerayların sarayına aidiyetini gösterecek herhangi bir maddi delil bulunmadığından, onun bu tahminine katılamıoruz.

70 Halim Giray, Gülbün-ü Hânân, s. 102.

71 Ekrem Hakkı Ayverdi, Avrupa'da Osmanl Mimarî Eserleri. Bulgaristan, Yunanistan, Arnavudluk, C IV/ Kitap 4-5-6 (İstanbul 1982), s. 129.

72 Ekrem Hakkı Ayverdi, Karinâbâd sâkinlerinden duyduğu kasabada artık mevcut olmayan bir "Kırım Hanları Hamamı”ndan söz etmektedir. Ayverdi, Avrupa'da Osmanh Mimarî Eserleri. Bulgaristan, Yunanistan, Arnavudluk, C IV/Kitap 4-5-6, s. 58. 
Ne var ki, Gerayların Bulgaristan'daki maddi izleri Türkiye'dekilerden çok daha fazla ve kasdî tahribata konu olmuştur. 1878 sonrası Bulgaristan hükûmetlerinin ülkedeki Osmanlı izlerini ortadan kaldırmak yönündeki sistematik (ve belli dönemlerde çok şiddetlenen) politikalarından Gerayların mirası payını bütünüyle almıştır. Bu durum tarih çalışmalarına da fazlasıyla yansımıştır. Esasen, birçok Bulgaristan hükûmetlerinin ve özellikle de komünist dönemin resmî ideolojisinin genel olarak Türk hakimiyeti dönemine karşı çizgisi, bu doğrultuyu izleyen birçok yazarın Gerayları ve onlardan kalan maddi ve sözlü izleri ya bütünüyle yok saymasına ya da ancak gayet olumsuz bağlamlar içinde zikretmesine yol açmıştır. Öte yandan, Bulgaristan’ın bağımsızlığını kazanmasını takip eden bir buçuk yüzyıla yakın süre içinde bazen sözünü ettiğimiz devlet politikalarına, bazen de tamamen mahallî teşebbüslere bağlı olarak Osmanlı döneminde inşa edilmiş sayısız cami, çeşme, hamam, türbe, mezar taşı ve başka yapılar geride hiçbir iz bırakılmamacasına ortadan kaldırılmıştır. Bunlar içinde Geraylara ait olan, sayısı tespit edilemeyecek kadar çok yapı da bulunmaktadır. Tespitlerimize göre, Bulgaristan sınırları dahilinde Gerayların yaşadığı 100'ün çok üzerinde ikametgâhtan (saray, konak ve ev) yalnızca Vırbiçe ve Atlıŏ̆lu köylerindekilerin kalıntıları günümüze gelebilmiştir.

Bulgaristan arazisinde sayısız Geray sülalesi mensubunun mezarının bulunduğu, bu meyanda, Âdil Geray Han ve Safa Geray Han'ın Karinâbâd'da, III. Gazi Geray Han, III. (Kara) Devlet Geray Han, Murad Geray Han ve II. Saadet Geray Han'ın ise Yanbolu'da defnedildikleri bilinmektedir. Ancak, bu kabirlerden hiçbiri bugün mevcut değildir. Yanbolu'da hanların ve diğer pek çok Geray’ın haziresine gömüldüğü Eski Cami halen ayaktaysa da, haziresinden hiçbir iz kalmamıştır ${ }^{73}$.

\section{Findiklı (Tenevo) Köyü/Yanbolu}

Geraylara ait olduğuna hiç şüphe bulunmayan bazı işlemeli mermer lahit parçalarını, Gerayların Rumeli’ndeki en önemli ikamet ve çiftlik yerlerinden biri olan Fındıklı (Tenevo) Kasabası'nda tespit edebildik. Sözünü ettiğimiz lahit parçaları köyün kilisesinin sunağının önündeki zemine döşenmiştir. Kilisenin 1895’te inşa edildiği bilindiğinden Geraylara ait mezarlığın da 1878-1895 arasındaki bir tarihte yok edilmiş olduğu anlaşılmaktadır. İki lahit parçasını da eskiden Gerayların konağının bulunduğu söylenen yere bitişik bir evin bahçesinde tespit ettik.

73 Eski Cami’nin içinde ana tarafından Geray hanedanına bağlanan Kırımlı İsmail Hakkı Paşa’nın mezarı halen mevcuttur. İsmail Hakkı Paşa son Osmanlı Sadrâzamı Kırımlı Ahmed Tevfik Paşa'nın babasıydı. 


\section{Maddi İzleri}

\section{İslimye (Sliven)}

İslimye Bölge Tarih Müzesi'nin (Regionalen istoriçeski muzey) ziyaretçilere açık olmayan deposunda iki Geray sultana ait mermer baştaşları bulunmaktadır. Bunlardan biri Saadet Geray Sultan (Paşa) zâde Salih Geray Sultan’a (ölümü: Hicrî 1277 [Milâdî 1860-1861]), diğgeri ise Arif Ahmed Geray Sultan zâde Maksud Geray Sultan'a aittir. Kâtibî kavuklu olan bu ikinci baştaşının mevtanın adı yazılı olan en üst satırının altı kırık olduğundan ölüm tarihi belirlenememektedir. İslimye Bölge Tarih Müzesi deposundaki üst üste yığılmış Osmanlı dönemi mezar taşları içindeki bazı kırık parçaların da Geraylara ait olması ihtimali vardır.

\section{Atlığlu (Konövo) Köyü/Yeni Zağra}

Geraylara ait kısmen de olsa ayakta kalabilmiş bir diğer ikametgâh yapısı ise Yeni Zağra'nın Atlıoğlu (Konövo) Köyü’ndeki Geray konağının bir kısmıdır. Ancak, bu yapı da yapılan tadilatlarla küçülmüş ve aslından çok uzaklaşmış olup, harap bir haldedir. Atlığlu Köyü'deki XVIII. yüzyıla ait olduğu tahmin edilen bir savunma kulesinin de Geraylar tarafindan inşa ettirildiği anlaşılmaktadır. Harap da olsa ayakta bulunan bu kulenin kitabesi mevcut değildir.

\section{Vırbiçe (Vırbitsa)/Şumnu}

Geray sülalesi mensuplarının 1970'lere kadar yaşamayı sürdürdükleri Şumnu'nun Vırbiçe (Vırbitsa) Kasabası, bu sülalenin Osmanlı topraklarındaki serencamının gayet ilginç dönemlerine ve şahsiyetlerine mekân olmuştur. Bir zamanlar Vırbiçe'deki varlıkları ve nüfuzları âdetâ efsane gibi anlatılan Geraylardan günümüze pek az maddi iz kalabilmiştir. Bunların en önemlisi Gerayların meşhur konağının kalıntılarıdır. Vırbiçe'de XVIII. yüzyıl sonlarından itibaren Geraylar tarafindan dört kere baştan inşa edildiği anlatılan konak 1970’lere kadar hayli iyi durumda ayakta kalabilmişti. Daha sonra hayli bakımsız kalan bu ahşap konak nihayet 1984 yılında burayı ellerinde meşalelerle basan bir şovenist grup tarafindan yakılmıştır. Günümüze söz konusu konağın yalnızca temelleri ile müştemilatından olan tek katlı ve iki odalı küçük ev (harap halde olmakla birlikte) ulaşabilmiştir. Bunlardan başka, Vırbiçe Kasabası'nda bir tepe üzerinde burada yaşamış Geray sülalesi mensuplarından birkaçına ait mezar taşları mevcuttur ${ }^{74}$. Kesin delile sahip olma-

$74 \mathrm{Bu}$ mezar taşlarının Geraylara ait olduğu bu sülale mensupları tarafindan kesin olarak teyit edilmekle birlikte, taşların üzerindeki yazılar okunamayacak derecede aşındığından kimlerin olduğu belirlenememektedir. 
makla birlikte, Vırbiçe'de halen mevcut ve faal olan eski caminin de Geraylarla ilişkili olduğu kanaatindeyiz.

\section{Bugünkü Yunanistan Sınırları Dahilinde Kalan Maddi İzler}

Geray hanedanı mensupları Osmanlı Devleti'nde yalnızca Rumeli'ndeki (ve istisnaî olarak başka yerlerdeki) çiftliklerinde ve İstanbul'da yaşamamışlardı. Birçok han, Geray sultan ve onların aile üyeleri kalabalık maiyetleriyle birlikte belirli müddetlerde sürgüne gönderilmiş oldukları Rodos, Midilli, Sakız, Kıbrıs, Bozcaada ve Limni gibi Akdeniz adalarında da ikâmet etmişlerdir. Bunlardan bazılarının bu adalarda doğdukları, vefat ettikleri, oralarda gömüldükleri ve birtakım mimari yapılar inşa ettirdikleri de biliniyor. Bu adalardan Kıbrıs'ta ve Bozcaada'da Geraylara ait her hangi bir maddî kalıntı tespit edemediğimiz gibi, böyle yapıların varlığına dair bir kayda da rast gelmedik. Bununla birlikte, Yunanistan sinırları dâhilinde kalan Rodos'ta Geray hanedanı üyelerine ait çok önemli bazı yapılar günümüze gelebilmiştir. Midilli'de vefat ederek orada Mekke Şeriflerinden Şerif Niam’n mezarı yakınlarında gömüldüğü kayıtlı bulunan ${ }^{75}$ Kuban Hanı Baht Geray Han'ın mezarına ait herhangi bir iz tespit edemedik. Diğger Ege adalarındaki araştırmalarımızda da Geraylara ait maddi izlerle karşılaşmadık.

\section{Rodos}

Rodos, en çok sayıda Geray hanedanı mensubunun mecburî ikamete gönderildiği adadır. Genel olarak Gerayların aileleri ve maiyetleri de burada kendileriyle birlikte yaşamaktaydı. Gerayların, özellikle de sâbık hanların adada mevkilerine uygun itibarı gördüklerine şüphe yoktur. Evliya Çelebi’ye göre, sâbık Kırım hanları Rodos Kalesi içinde limana bakan ve 70 odası bulunan Şövalyelerden kalma büyük bir sarayda ikamet etmekteydi ${ }^{76}$. Evliya Çelebi’nin bahsettiği bu sarayın, (Mussolini devri İtalyan restorasyonu ile orijinalliğinden hayli uzaklaşmış olmakla birlikte) bugün de ayakta olan ve 150'den fazla odası bulunan Hospitaller (Saint Jean) Şövalyelerinin Büyük Üstadı'nın sarayı yahut onun bir bölümü olduğu bellidir. Hanlar yahut diğer Geraylar XVII. yüzyılda (yahut o yüzyıl içinde bir dönemde) Evliya Çelebi’nin sözünü ettiği sarayda ikamet etmiş olsalar da, sonraki zamanlarda başka ikametgâhlarda yaşamışlardır.

Rodos’ta yaşamış sâbık Kırım hanlarından II. Hacı Geray Han burada bir de

75 Halim Giray, Gülbün-ü Hânân, s. 113.

76 Evliya Çelebi, Evliyâ Çelebi Seyahatnâmesi, IX. Kitap, Hazırlayanlar: Seyit Ali Kahraman-Yücel Dağlı-Robert Dankoff, İstanbul 2005, s. 126. 


\section{Maddi İzleri}

vakıf kurmuştu. 1728'e ait bir kayıttan bu vakfin gelirlerinden bir türbedara maaş verildiği görülmektedir ${ }^{77}$. Burada zikredilen türbenin II. Hacı Geray Han'ın kendi türbesi yahut kabri ile alakalı olduğuna kesin gözüyle bakılabilir. Diğer bir ifadeyle, II. Hacı Geray Han kendisine ait bir türbeye gömülmüş̧ü. II. Hacı Geray Han'ın ağabeyi olup yine Rodos'ta vefat etmiş olan II. Saadet Geray Han'ın ise, II. Hacı Geray Han'ın türbesi yakınlarında defnedildiği bilinmektedir ${ }^{78}$. Bu iki hana ait herhangi bir türbe yahut mezar taşı günümüze ulaşamamıştır.

Kırım hanlarından Canıbek Geray Han, II. Hacı Geray Han, II. Saadet Geray Han ve Şahin Geray Han Rodos'ta ölüp orada gömülmüşler, I. Kaplan Geray Han ve II. Meñli Geray Han ise Rodos'ta dünyaya gelmişlerdir. Tahta çıkmamış Geray sultanlardan hangilerinin Rodos'ta dünyaya geldiğini ve hangilerinin de orada öldügünü kesin sayllarıyla belirleyebilmek mümkün değildir. Günümüze yalnızca Canıbek Geray Han ile üç Geray sultan ve bir de han annesine (ana beyime) ait kabirler ulaşabilmiştir.

Diğer Geray türbeleri ve kabirleri ortadan kalkmış olsa da, halen mevcut olan iki türbe ve mezar taşları büyük önemi haizdir. Murad Reis külliyesinin mezarlığında bulunan bu türbeler Geray hanedanına ait Kırım dışında mevcut yegâne türbeleri teşkil etmektedir. Söz konusu türbelerden birinde Canıbek Geray Han yatmaktadır. Aynı türbede I. Kaplan Geray Han'ın annesi ve I. (Hacı) Selim Geray Han'ın hanımı Beyzâde Sultan'ın da (ölümü: Hicrî 1134 [Milâdî 1721-1722) kabri bulunmaktadır. Canıbek Geray Han'ın türbesi büyük ihtimalle IV. Mehmed Geray Han'ın annesi ve I. Selâmet Geray Han'ın hanımı Dâver Bike Sultan tarafindan inşa ettirilmiştir. Nitekim, Canıbek Geray Han Türbesi'nin bakımı ile türbedar ve cüzhânının giderlerini karşılamak maksadıyla teşkil edilmiş olan vakfin kurucusu Dâver Bike Sultan'dı ${ }^{79}$. Canıbek Geray Han'ın türbesi ve onun içindeki

77 Vakıflar Genel Müdürlüğü Arşivi (Ankara) (VGMA), Defter no. 2383, s. 18.

78 Uğur Demir, “Târih-i Mehmed Giray (Değerlendirme-Çeviri Metin)”, Yayınlanmamış Yüksek Lisans Tezi, Marmara Üniversitesi, İstanbul 2006, s. 52.

79 Mehmet Akif Erdoğdu, "Rodos Adasındaki Osmanlı Evkafi (1522-1711)", Tarih İncelemeleri Dergisi, S. 15, İzmir 2000, s. 27. 1701 tarihli bir belge Canıbek Geray Han Türbesi’nin türbedarlığının ve cüzhânlığının tevcihi hakkındadır. BOA, Cevdet-Evkaf, Dosya no.: 62, Gömlek no.: 3062. Canıbek Geray Han’ın babası Mübarek Geray Sultan erken yaşta vefat etmiş, Adıgelerin Besleney kabilesinden bir prenses olan annesi de kadim geleneklere göre, önce I. Fetih Geray Han, sonra da I. Selâmet Geray Han ile evlenmişti. I. Selâmet Geray Han, yetim yeğeni Canıbek Geray Sultan'ı öz evlâdı gibi benimsemişti. Halim Giray, Gülbün-ü Hânân, s. 54. Dâver Bike Sultan Canıbek Geray Han'ın annesi olmasa da, kocası I. Selâmet Geray Han'ın Canıbek Geray'a olan sevgisinden dolayı bu vakfı ve (büyük ihtimalle) türbeyi kurdurmuş olmalıdır. 
lahdi günümüzde de (2013 yılı itibarıyla restorasyona ihtiyaç göstermekle birlikte) ayaktadır $^{80}$. Ancak, Evliya Çelebi'nin Canıbek Geray Han’ın türbesinin kapısında gördüğünü kaydettiği "Şu serverler ki dağlar gibi baş eğmezdi eflâke/Yatarlar yerde best olmuş ne tîg u ne kemer peydâ" beyti yazılı olan kitabe günümüzde mevcut değildir ${ }^{81}$.

Aynı mezarlıkta bulunan bir diğer türbe ise, kaderin bir cilvesi olarak, Canıbek Geray Han’ın can düşmanı sayılabilecek olan Saadet Geray Sultan zâde Kalgay Şahin Geray Sultan'a aittir. Bu türbede Şahin Geray Sultan’ın yanı sıra Fetih Geray Sultan da medfundur. Şahin Geray Sultan türbesinin dışında ise (baba adını bilemediğimiz) Saadet Geray Sultan’ın (ölümü: Hicrî 1066 [Milâdî 1655-1656]) kabri vardır.

Rodos Şehri'nde Şövalyeler Yolu (Uzun Yol / bugünkü İppoton Sokağı) üzerinde bulunan Hanzâde Mescidi muhtemelen Kırım hanzâdelerinden biri tarafindan eski bir kiliseden mescide çevrilmiş olduğu için bu adı taşımaktaydı. Hanzâde Mescidi 1974 sonrasında Aya Triada (Mukaddes Teslis) adıyla tekrar kiliseye çevrilmiştir.

Adından dolayı Geraylarla ilgili olduğuna kesin gözüyle bakılabilecek bir diğger mescit de Rodos Kalesi dışında bulunduğunu bildiğimiz Kırımlı Mescidi’dir. Kırımlı Mescidi'nin idamesi için bir de vakıf kurulmuştu² ${ }^{82}$ Kırımlı Mescidi günümüze ulaşamamıştır.

\section{Osmanlı Devleti'ndeki İkamet Yerlerinde Geraylardan Kalan Sözlü Miras}

Geray hanedanı mensuplarının yaşamış oldukları yerlerdeki izleri yalnızca maddi kalıntılardan ibaret değildir. O yerlerde anlatılmaya devam eden söylentiler, hikâyeler, toponimler ve başka sözlü tarih verileri de somut olmayan kalıntıları teşkil eder. Hatta gerçek dışı rivayetler dahi onlar hakkındaki popüler imajın bir yansıması olmaları bakımından önemlidir. Bu gibi bazı sözlü tarih verilerine yahut genel olarak somut olmayan kültürel izlere ulaşabildiysek de, bu açıdan olması beklenenden çok daha fazla ölçüde veri kaybının veya kültürel kopukluğun bulun-

80 2000'lerin başlarında Canıbek Geray Han lahdindeki baş ve ayak taşları kırılarak lahitten ayrılmış durumdaydı. 2013'teki ziyaretimizde lahit tamir edilmiş ve her iki taş da lahde raptedilmişti.

81 Evliya Çelebi, Evliyâ Çelebi Seyahatnâmesi, IX. Kitap, s. 131.

82 Ali Fuat Örenç, Yakm Dönem Tarihimizde Rodos ve Oniki Ada, İstanbul 2006, s. 367. 


\section{Maddi İzleri}

duğunu gördük. Günümüz Türkiyesi sınırları içinde bulunan ve Geray hanedanı mensuplarının ikamet ettikleri belgelerle sabit olan köy ve diğer yerleşim yerlerinin çok büyük kısmında günümüzde orada yaşayan sâkinlerin, geçmişte Gerayların o mahalde yaşadıklarından bütünüyle habersiz olduklarını müşahede ettik. Bu bilgisizlikte, hâlen buralarda sâkin olan insanların büyük çoğunluğunun Rumeli’nin günümüzde Türkiye dışında kalan yerlerinden göçmen olarak gelmiş olmalarının, dolayısıyla atalarının Gerayların bulunduğu devirlerde o yerleşim yerlerinde yaşamamıs olmasının önemli bir payı bulunmaktadır. XVIII. ve XIX. yüzyıllarda oralarda yaşamış yerli ahaliden Müslüman olanların ahfâdı pek çoğu bugün başka yerlere gitmiş olduğu gibi, Bulgar, Rum, Gagauz ve Yahudi gibi gayri-Müslim yerli sâkinlerden de tek bir kişi kalmamıştır. Bütün bunlar mikro seviyelerde sosyal hafizanın en fazla bir yüzylldan geriye gidememesine, ondan öncesinin ise tamamen silinmesine yol açmıştır.

Gerayların yaşadığı ve bugün Bulgaristan sınırları dahilinde kalan bölgelerde de sosyal hafiza açısından durum çok farklı değildir. Son iki yüzyıl içinde, Yanbolu, İslimye, Karinâbâd, Eski Zağra, Yeni Zağra, Aydos ve Burgaz’n köylerinin pek çoğunda büyük nüfus değişmeleri yaşanmış, köy sâkinleri kitle hâlinde köyden göç etmiş, yerlerini başka yerlerden gelenler almış, etnik ve dinî yapı radikal şekilde değişmiştir. Bu bölgenin köylerindeki Hristiyan unsurlardan birçoğu 1828-1829 Osmanlı-Rus Savaşı sonrasında Besarabya'ya göç etmiş, Müslüman/Türk ahalinin pek çoğu ise 1877-1878 Savaşı'nı takiben buraları terk etmiş, müteakip yıllarda farklı yerlerden gelen Hristiyan/Bulgar halk bu köylere iskân edilmiştir. Bu durum ise, ayn Türkiye'de olduğu gibi köylerin geçmişlerine ait bilgilerin nesilden nesile iletilmesinde büyük kopukluklara yol açmıştır. Eskiden Geray çiftliklerinin bulunduğu bu köylerde yalnızca son birkaç nesildir yaşamakta olan şimdiki nüfus çoğunlukla köylerinin Geraylara uzanan tarihinden hiç haberdar değildir. Yine de, bazı halk hikâyelerinde ve türkülerde Geraylara atıfta bulunulduğuna rastlanmaktadır. Bu gibi hikâye ve türkülerin birçoğunda da, söz konusu Gerayların "Türk beyi” yahut "Türk paşası" gibi sıfatlarla anıldıkları, onların gerçek kimliklerinin unutulmuş veya karıştırılmış olduğu da görülmektedir.

Bu makalemizde ele aldığımız Geray sülalesi mensuplarına ait yapılar ve maddi izler esas olarak bütün yahut kalıntı hâlinde günümüze ulaşabilenlerden oluşmaktadır. Bunların büyük bir kısmı mezar taşlarıdır. Çalışmamızda yalnızca Osmanlı devrine ait mezar taşlarına ve lahitlere yer verirken, Geray sülalesi mensuplarının 
Cumhuriyet sonrası dönemdeki mezar taşlarını yahut diğer maddi izlerini (bir örnek dışında) konumuza dahil etmedik.

Geray hanedanının Osmanlı topraklarında geçirdiği zamanın ve coğrafi dağılımının genişliği göz önüne alındığında onlardan günümüze kalabilen maddi izler çok sınırlı sayıdadır. Varlı̆̆ı hakkında kayıtlar bulunmayan eserler bir yana, yalnızca kaynaklardan mevcudiyetini öğrendiğimiz ancak hâlen mevcut olmayan eserlerin bile miktarı çok fazladır. Günümüze gelebilen maddi izlerin çoğunluğu ise gayet harap durumda olup tamire ve bakıma muhtaçtır. Geray hanedanının kendi vatanı olan Kırım'daki maddi izlerinin muazzam bir tahribata maruz kaldığı ve büyük çoğunluğunun ebediyen yok olduğu hatırlanırsa, bugünkü Türkiye, Bulgaristan ve Yunanistan sınırları dahilinde kalabilen pek az sayıdaki eserin muhafazasının nasıl bir önemi haiz olduğu anlaşılabilir. 


\section{KAYNAKLAR}

Abdullah ibn Rıdvan, Tevârîh-i Deşt-i Kipçak 'an Hitta-i Kirmm veya Tevârîh-i Tatar Hânân-ı Kadîm ve Ahvâl-i Deşt-i Kipçak, Hazırlayanlar: M. Akif Erdoğdu-Selçuk Uysal, İzmir 2012.

Acar, Serkan, Kazan Hanlı̆g-Moskova Knezliği Siyasi Ilişkileri (1437-1552), Ankara 2013.

Altan, Kemal, "Meşhur (Kırım Giray)ların Mezarları, Akşam İstanbul 3 Temmuz 1941.

Altan, Mazhar, "Mimar Kemal Altan", Arkitekt, S. 199-200 (İstanbul 1948)), s. 178-179.

Ayverdi, Ekrem Hakkı, Avrupa'da Osmanlı Mimarî Eserleri. Bulgaristan, Tunanistan, Arnavudluk, G IV, Kitap: 4-5-6, İstanbul 1982.

Bayev, Haralambi, "Zagadıçni ruini nasred Yambol ili dvoretsıt, koyto ne zavelyazvame", Vreme (Yanbolu), S. 11 (824) (9-15 Nisan 2015), s. 7.

Baysalan, Şerif, Gelmişi Geçmişi Bugünüyle Hayrabolu, Tekirdağ 2006.

Bursalı Mehmed Tahir, Idare-i Osmaniyye Zamanında Yetişen Kirnm Müellifleri İstanbul 1919.

Câbî Ömer Efendi, Câbî Tarihi, C 2, Hazırlayan Mehmet Ali Beyhan, Ankara 2003.

Caferzade Mehmet Tevfik, [Selen], Tarihte Hayrabolu ve Çeuresi, Hazırlayan: Aydın Oy, Tekirdağ 1989.

Çınar, Hüseyin, “Arslan Giray Han ve Kırım’ın Yeniden İmârında Vakıfların Rolü”, Vakıflar Dergisi, C XXX (Ankara 2007), s. 117-138.

Decei, Aurel, 'Etablissement de Aktav de la Horde d'Or dans l'Empire Ottoman, au temps de Yıldırım Bayezid", 60. Doğum Yil Münasebetiyle Zeki Velidi Togan'a Armağan, İstanbul, 1950-1955, s. 77-92.

Demir, Aydoğan, "I. Kaplan Giray Han'ın Mezar Taşı", Tarih ve Toplum, S. 136 (İstanbul Nisan 1995), s. 21-26 (213-218).

Demir, Uğur, "Târih-i Mehmed Giray (Değerlendirme-Çeviri Metin)", Yayınlanmamış Yüksek Lisans Tezi, Marmara Üniversitesi, İstanbul 2006. 
Erdoğdu, Mehmet Akif, "Rodos Adasındaki Osmanlı Evkafi (1522-1711)", Tarih Incelemeleri Dergisi, S. 15, İzmir 2000, s. 9-30.

Esin Mete, "Giraylar ve Vize”, Kirm (Ankara), S. 10, (Ocak-Şubat-Mart 1995), s. 23-24.

Evliya Çelebi, Evliyâ Çelebi Seyahatnâmesi, kitap III, Hazırlayanlar: Seyit Ali Kahraman-Yücel Dağlı, İstanbul 1999.

Evliya Çelebi, Evliyâ Çelebi Seyahatnâmesi, kitap VII, Hazırlayanlar: Seyit Ali Kahraman-Yücel Dağll-Robert Dankoff, İstanbul, 2003.

Evliya Çelebi, Evliyâ Çelebi Seyahatnâmesi, kitap VIII, Hazırlayanlar: Seyit Ali Kahraman-Yücel Dağhl-Robert Dankoff, İstanbul, 2003.

Evliya Çelebi, Evliyâ Çelebi Seyahatnâmesi, kitap IX, Hazırlayanlar: Seyit Ali Kahraman-Yücel Dağlı-Robert Dankoff, İstanbul 2005.

Eyice, Semavi, "Mezarlıklar ve Hazireler", İslâm Dünyasında Mezarlıklar ve Defin Gelenekleri, C I, Ankara 1996, s. 122-134.

İbn Kemal (Kemalpaşazâde), Tevârih-i Âl-i Osman. IV. Defter Hazırlayan: Koji Imazawa, Ankara 2000.

İşli, Necdet, "Tatarhaniler yahut Zindan Altı Mezarlığı", Arkitekt, S. 433, (1996), s. $48-49$.

Halim Giray [Halim Geray Sultan], Gülbün-ü Hânân (Kimm Hanlan Tarihi). Değerlendirme-Metin-Tıpkıbasım, Hazırlayanlar: Alper Başer-Alper Günaydın, İstanbul 2013.

[Hayrabolulu Hasîb], Hayrabolulu Hasîb Dî̀ân, Hazırlayanlar: Ramazan Ekici-Suat Donuk, Ankara 2015.

Hudyakov, Mihail Georgiyeviç, Oçerki po istorii Kazanskogo hanstva, Moskova 1991.

Kançal-Ferrari Nicole, "Kırım Hanlarının İmar Faaliyeti ve Mezar Taşları", Yayımlanmamış Yüksek Lisans Tezi, İstanbul Üniversitesi, İstanbul 1997.

Kançal-Ferrari Nicole, "Saray’a Bağlı Bir Cami ve Haziresi: Kırım Hanlığı’nın Payitahtı Bahçesaray'daki Hansaray'ın Haziresi”, Belleten, C LXVI/S. 246, (Ağustos 2002), s. 371-420.

Kırımlı Hakan-Nicole Kançal-Ferrari (Proje Yöneticileri), Hakan Kırıml-Nicole 
Ferrari-Kançal - Gökçe Günel - İbraim Abdulla - Nariman Abdülvaap - Safiye Eminova - Gülşen Dişli (Yazarlar), Kirm'daki Kirm-Tatar (Türk-İslâm) Mimarî Yadigârları, Ankara 2021.

Koçu, Reşat Ekrem, "Çatalca Sarayları", Tercüman (İstanbul), 14, 15, 16, 17, 21 , 22, 23, 24 Şubat 1970.

Meriç, Rıfkı Melül, "Trakya Kitabeleri I. Hayrabolu Kitabeleri”, Tarih Vesikalan, Yeni Seri, G I/S. 2 (17), (İstanbul Ocak 1958), s. 210-220.

Oruç Beğ, Oruç Beğ Tarihi, Hazırlayan: Atsız, İstanbul, t.y. [1972].

Örenç, Ali Fuat, Yakın Dönem Tarihimizde Rodos ve Oniki Ada, İstanbul, 2006.

Özer, Mustafa, "Pınarhisar Çevresindeki Osmanlı Dönemi Yapıları", Yöre, S. 8687 (Edirne Mayıs-Haziran-Temmuz 2007, s. 43-59.

Rus Elçi Raporlarnda Astrahan Seferi, Hazırlayan: İlyas Kamalov, Ankara 2011.

Seyyid Mehmed Rızâ, Es-Seb’üs-Seyyâr fi Ahbâr-ı Mülûki’t-Tatar (İnceleme-Tenkitli Metin), Hazırlayan: Yavuz Söylemez, Ankara 2020).

Smirnov, Vasiliy Dmitriyeviç, Krrmskoe hanstvo pod verhovenstvom otomanskoy portı do naçala XVIII veka, Sankt Petersburg 1887).

Solak-zâde Mehmed Hemdemî Çelebi, Solak-zâde Tarihi, C 2, Hazırlayan: Vahid Çabuk, Ankara 1989.

Söylemez Yavuz, "Kırım Hanlığı-Osmanlı Devleti Siyasi İlişkilerinde Rehin Usulü”, Türk Tarihi Araştrmalan Dergisi, C IV/S. 2 (Güz 2019), s. 84-109.

Tott François Baron de [Tóth Ferenc], Memoirs of Baron De Tott, C. I, Londra, 1785. Uzunçarşılı, İsmail Hakkı, Osmanh Tarihi, C III/Kısım II, Ankara 1995. 


\section{EKLER}

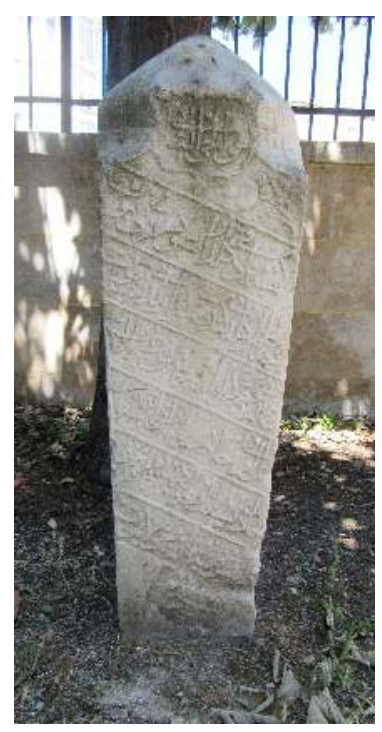

Resim 1: II. Fetih Geray Han 22 Şaban 1159 Saray Ayas Paşa Camii haziresi

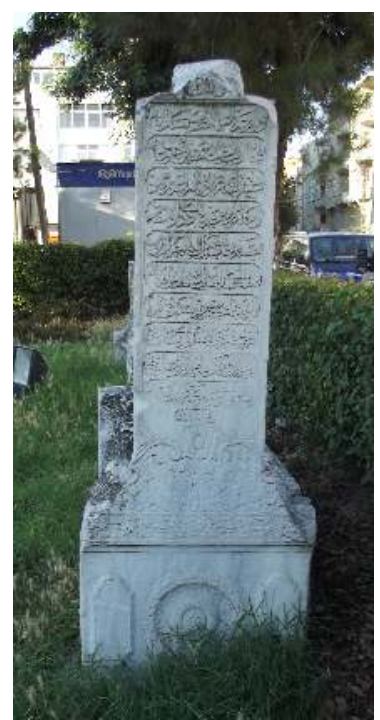

Resim 3: IV. Devlet Geray Han Ramazan 1194 Saray Ayas Paşa Camii haziresi

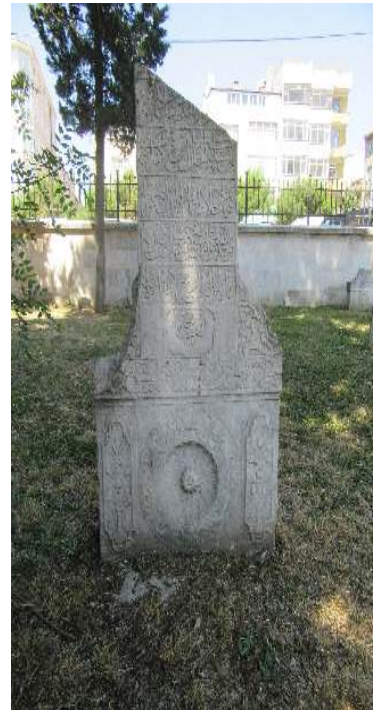

Resim 2: II. Selim Geray Han 1200 Saray Ayas Paşa Camii haziresi

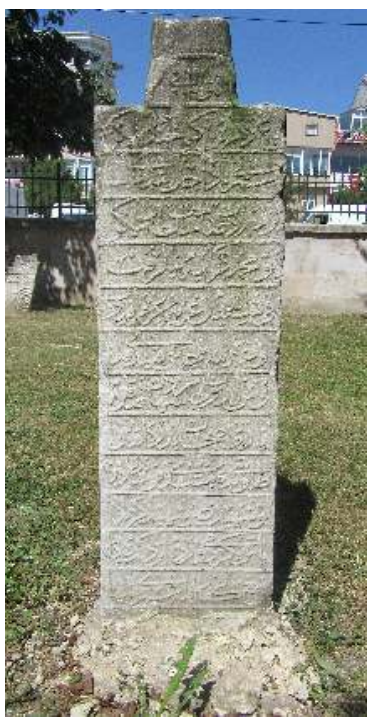

Resim 4: Mehmed Geray Sultan 12. Şehit taşı Saray Ayas Paşa Camii haziresi

Belleten, Aralık 2021, Cilt: 85/Sayı: 304; 889-931 

Maddi İzleri

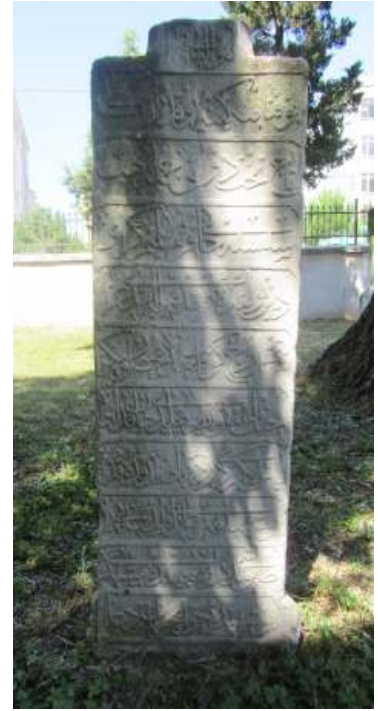

Resim 5: Selim Geray Sultan 1255 Şehit taş1 Saray Ayas Paşa Camii haziresi

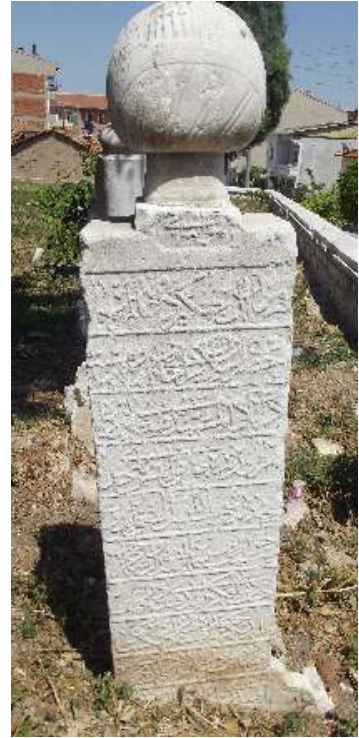

Resim 6: Kalgay Mübarek Geray Sultan (Arslan Geray Han'ın oğlu) 1203

Çelebi Sultan Mehmed Camii (Paşa Camii) haziresi

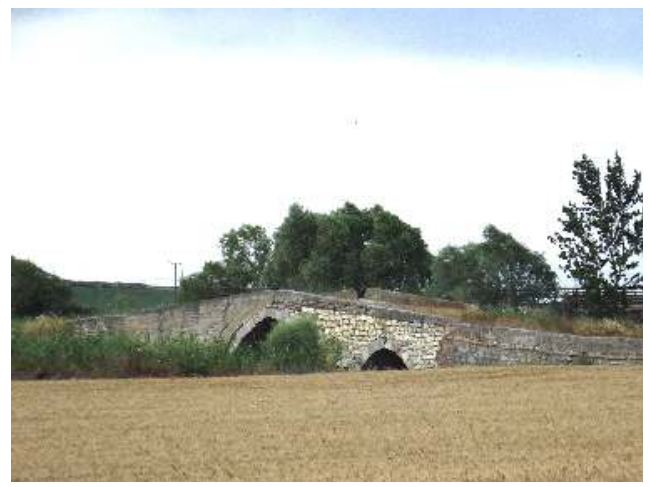

Resim 7: III. Selim Geray Han Köprüsü Karabürçek Köyü (2012)

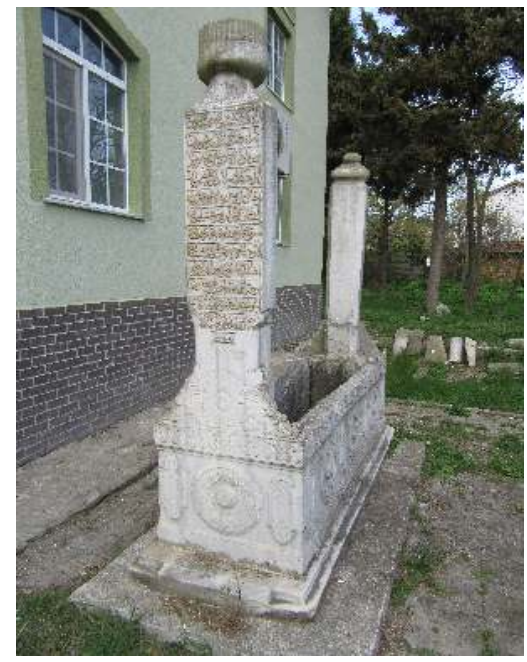

Resim 8: II. Kaplan Geray Han 1185 Subaşı Camii haziresi 


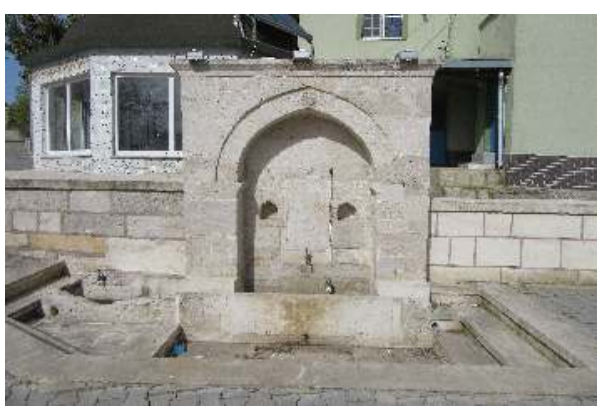

Resim 9: Selim Geray Sultan Çeşmesi Subaş1-Çatalca

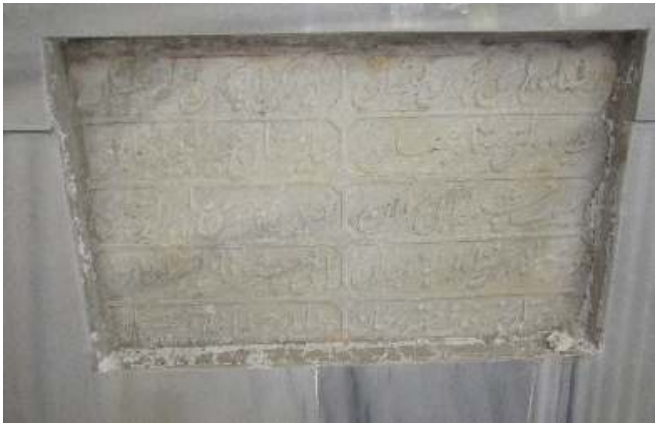

Resim 11: Selim Geray Sultan'ın kızı Fatma Sultan'ın çeşme kitabesi Oklalı köyü camii gasılhanesinin içinde

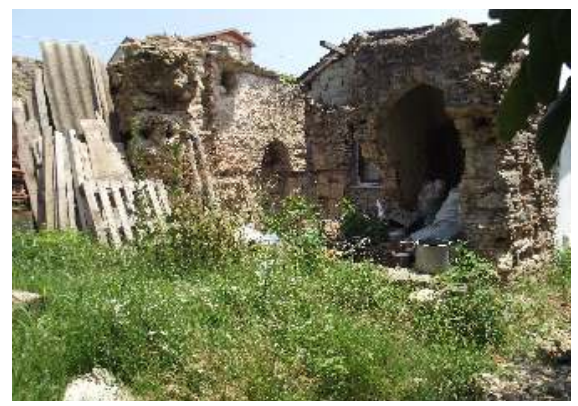

Resim 10: Hamam kalıntısı Subaşı Köyü 15 Haziran 2013

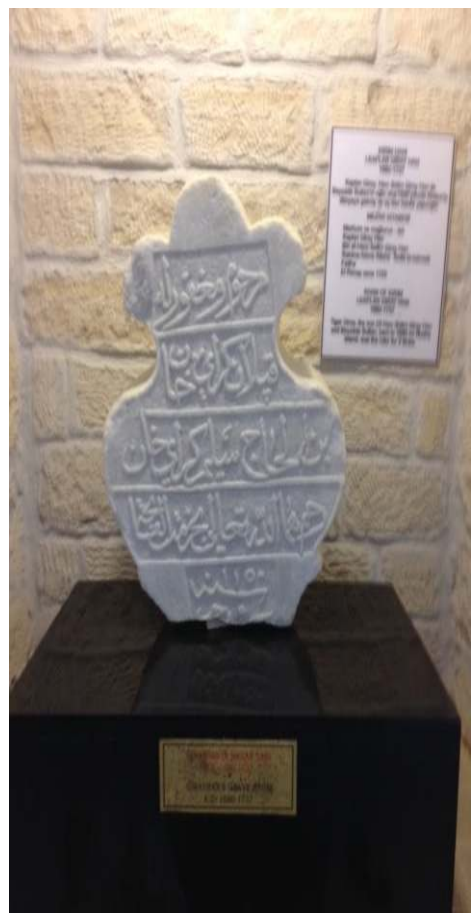

Resim 12: I. Kaplan Geray Han'ın baştaşıÇeşme Kalesi müzesi

Belleten, Aralık 2021, Cilt: 85/Sayı: 304; 889-931 


\section{Maddi İzleri}

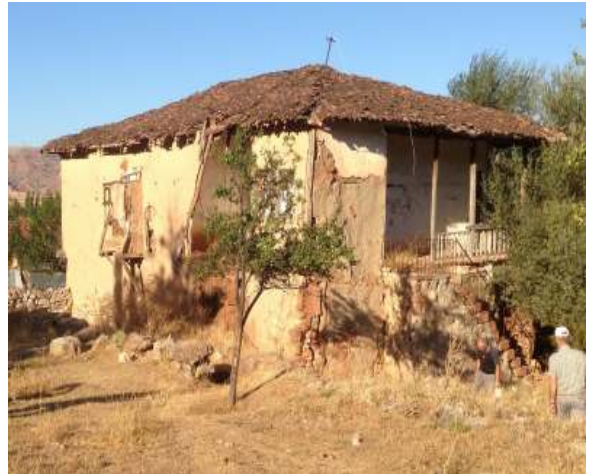

Resim 13: Gerayların konağ1-Güzelbeyli Kasabas1-Zile

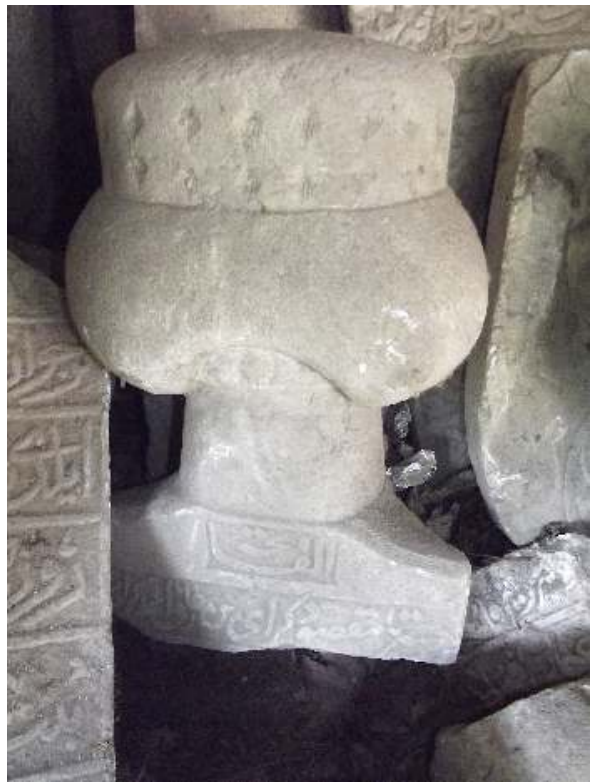

Resim 15: Maksud Geray bin Arif Ahmed Geray Sultan'ın mezartaşı

(İslimye Bölge Tarih Müzesi, 2016)

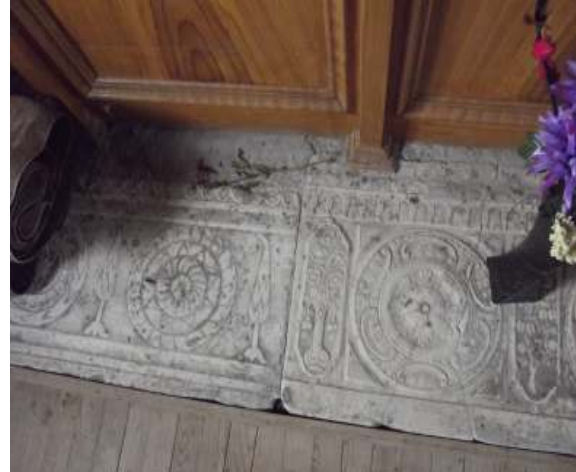

Resim 14: Fındıklı Kilisesi'nin içindeki lahit parçaları (Ağustos 2015

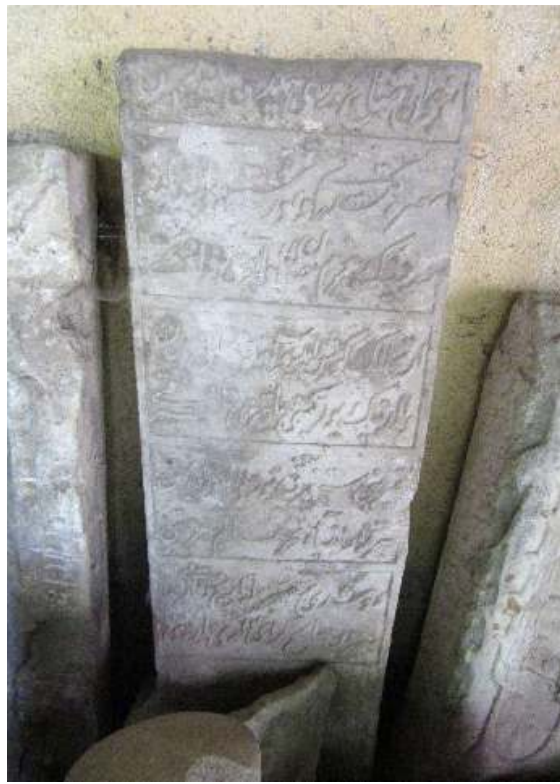

Resim 16: Salih Geray Sultan'ın mezartaşı (İslimye Bölge Tarih Müzesi, 2016) 


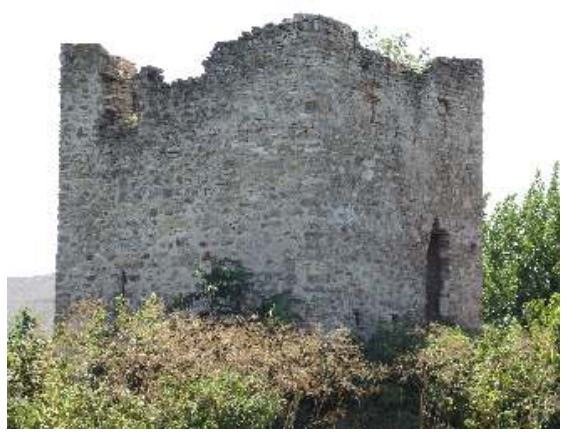

Resim 17: Kule-Atlıoğlu (Konövo) Köyü (Yeni Zağra)

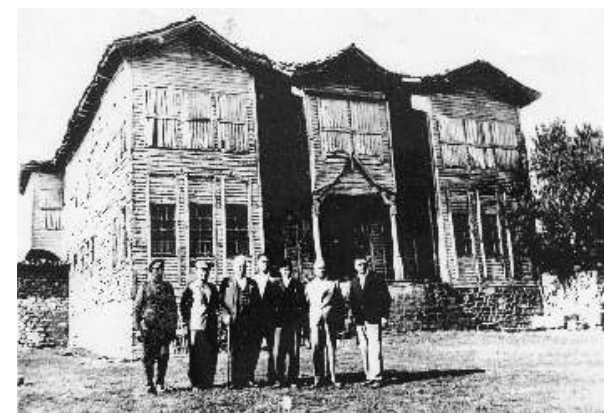

Resim 19: Gerayların Vırbitsa'daki Sarayı (Mehmed Ali Geray sağdan üçüncü)

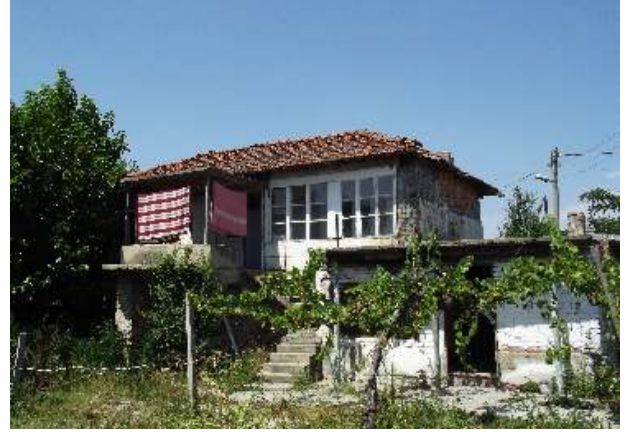

Resim 18: Atlıŏglu (Konövo) Köyü'ndeki (Yeni Zağra) Geraylara ait konak (2015)

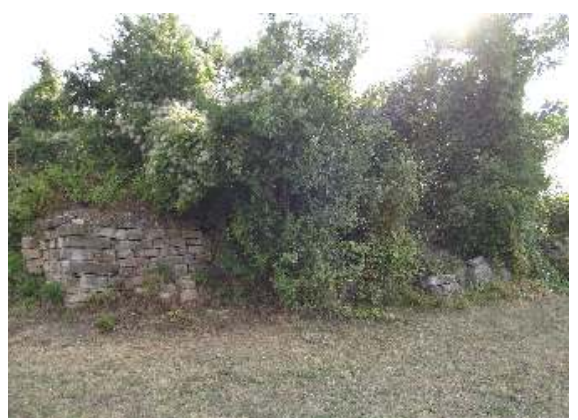

Resim 20: Virbitsa Kasabası, Gerayların Sarayından geriye kalanlar (ikinci avludan görünüş) (2015)

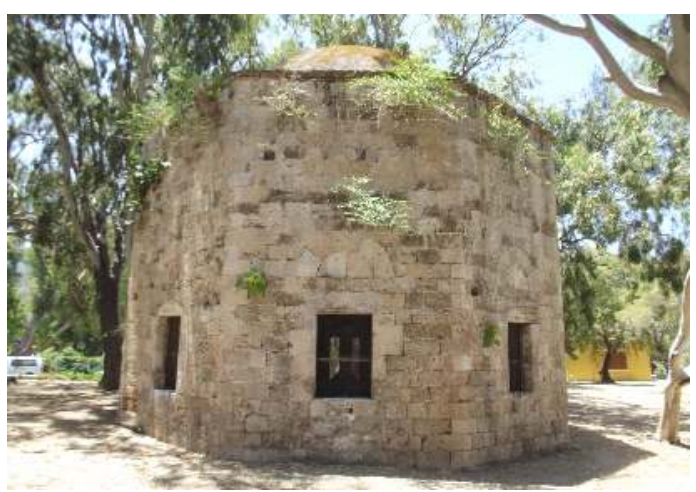

Resim 21: Canıbek Geray Han türbesi Murat Reis Mezarlığı Rodos (23.6.2013) 

Maddi İzleri

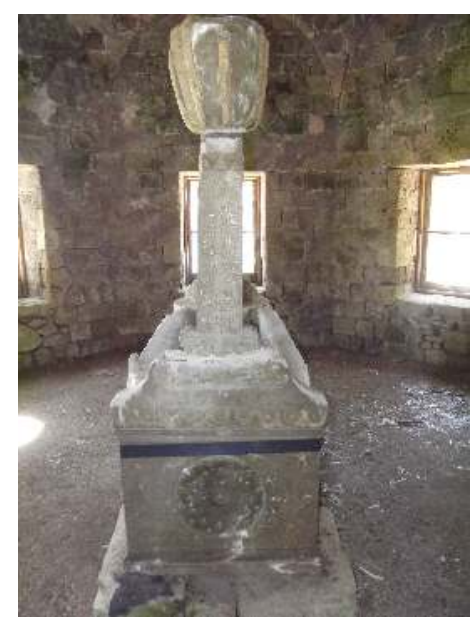

Resim 22: Canıbek Geray Han Murat Reis Mezarlığı Rodos (23.6.2013)

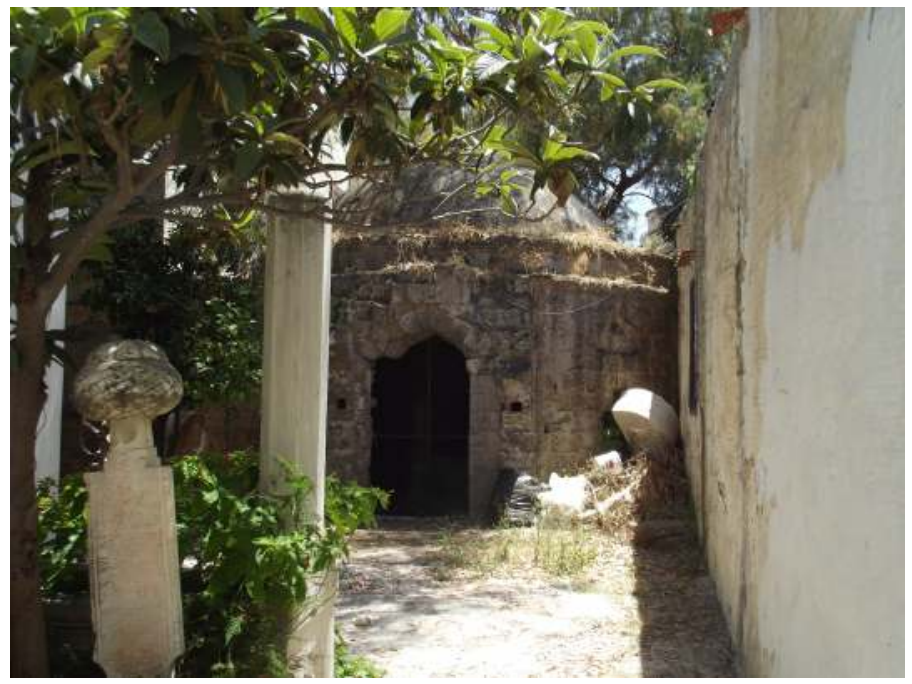

Resim 23: Şahin Geray Sultan ve Fetih Geray Sultan türbesi Murad Reis Mezarlı̆ğ Rodos (23.6.2013) 